\title{
Detoxification capacity and protective effects of medicinal plants (part 2): plant based review
}

\author{
Prof Dr Ali Esmail Al-Snafi \\ Department of Pharmacology, College of Medicine, Thi qar University, Iraq
}

\begin{abstract}
Modern research has shown that a wide range of plants can neutralize or detoxify toxins and protect the body from the toxic effects of drugs and chemicals. These plants included: Agrimonia eupatoria, Alhagi maurorum, Allium sativum, Alpinia galangal, Anchusa strigosa, Arctium lappa, Artemisia campestris, Asparagus officinalis, Astragalus hamosus, Bauhinia variegata, Benincasa hispida, Brassica nigra, Brassica rapa, Bryonia dioica, Bryophyllum calycinum, Caesalpinia crista, Calendula officinalis, Calotropis procera, Canna indica, Capparis spinosa, Capsella bursa-pastoris, Capsicum frutescens, Capsicum frutescens, Carthmus tinctorius, Carum carvi, Cassia occidentalis, Casuarina equisetifolia, Celosia cristata and Chenopodium album. This review will highlight the detoxification ability of the medicinal plants especially hepato- and nephro-protective effects of these medicinal plants.
\end{abstract}

Keywords: detoxification, toxins, poisons, plants, herbs, hepatoprotective, renoprotective

\section{INTRODUCTION}

In alternative medicine, the toxins were removed from the body with the using of herbal treatments [1]. Modern research has shown that a wide range of plants can neutralize or detoxify toxins and protect the body from the toxic effects of drugs and chemicals. These plants included: Agrimonia eupatoria [2], Alhagi maurorum [3], Allium sativum[4], Alpinia galangal [5], Anchusa strigosa [6], Arctium lappa [7], Artemisia campestris [8], Asparagus officinalis [9], Astragalus hamosus [10], Bauhinia variegate [11], Benincasa hispida [12], Brassica nigra [13], Brassica rapa [13-14], Bryonia dioica [14], Bryophyllum calycinum [15], Caesalpinia crista [16], Calendula officinalis [17], Calotropis procera [18], Canna indica [19], Capparis spinosa [20], Capsella bursa-pastoris [21], Capsicum frutescens and Capsicum frutescens [22], Carthmus tinctorius [23], Carum carvi [24], Cassia occidentalis [25], Casuarina equisetifolia [26], Celosia cristata [27] and Chenopodium album [28]. This review will highlight the detoxification ability especially hepato- and nephro-protective effects of the medicinal plants as a second part of our previous review [14,29].

\section{Plants with detoxifying capacity: Cicer arietinum}

The hepatoprotective activity of petroleum ether, methanol and aqueous extracts of aerial parts (except fruits) of Cicer arietinum $\mathrm{L}$ was studied against $\mathrm{CCl}_{4}$ induced hepatotoxicity in rats. The plant extracts were administered to the experimental rats ( 200 and $400 \mathrm{mg} / \mathrm{kg} / \mathrm{day}$ po for 20 days). The Hepatoprotective activity of these extracts was evaluated by liver function biochemical parameters (serum glutamic pyruvic transaminase, serum glutamic oxaloacetic transaminase, serum alkaline phosphatase, total bilirubin, lipid peroxidation, superoxide dismutase, catalase, reduced glutathione) and histopathological studies of liver. Pre-treatment of the rats with petroleum ether, methanol and aqueous extract prior to $\mathrm{CCl}_{4}$ administration caused a significant reduction in the values of SGOT, SGPT, SALP, LPO, total bilirubin and significant increase in SOD, CAT, GSH $(\mathrm{P}<0.01)$, almost comparable to the Silymarin. The hepatoprotective activity was confirmed by histopathological examination of the liver tissue of control and treated animals. Histology of liver sections of the animals treated with the extracts showed the presence of normal hepatic cords, absence of necrosis and fatty infiltration [30-31].

\section{Cichorium intybus}

The hepatoprotective activity of aqueous-methanolic extract of Cichorium intybus seeds was investigated against acetaminophen and $\mathrm{CCl}_{4}$-induced hepatic damage. Acetaminophen produced $100 \%$ mortality at the dose of $1 \mathrm{~g} / \mathrm{kg}$ in mice while pretreatment of animals with plant extract $(500 \mathrm{mg} / \mathrm{kg})$ reduced the death rate to $30 \%$. Acetaminophen at the dose of $640 \mathrm{mg} / \mathrm{kg}$ produced liver damage in rats as manifested by the significant $(\mathrm{P}<0.01)$ rise in serum levels of alkaline phosphatase (ALP), GOT and GPT to $393 \pm 28,767 \pm 215$ and $692 \pm 191 \mathrm{IU} / \mathrm{l}$ respectively, compared to respective control values of $198 \pm 15,76 \pm 07$ and $39 \pm 09$ IU/l. Pretreatment of rats with plant extract $(500 \mathrm{mg} / \mathrm{kg})$ significantly lowered $(\mathrm{P}<0.01)$ the respective serum ALP, GOT and GPT levels to $228 \pm 16,68 \pm 10$ and $41 \pm 08$ IU/l. Similarly, a hepatotoxic dose of $\mathrm{CCl}_{4}(1.5 \mathrm{ml} / \mathrm{kg}$; 
orally) significantly raised $(\mathrm{P}<0.01)$, the serum ALP, GOT and GPT levels to $312 \pm 20,503 \pm 98$ and $407 \pm 109$ IU/l respectively, compared to respective control values of $215 \pm 16,79 \pm 18$ and $49 \pm 10 \mathrm{IU} / \mathrm{l}$. The same dose of plant extract $(500 \mathrm{mg} / \mathrm{kg})$ was able to prevent significantly $(\mathrm{P}<0.05)$ the $\mathrm{CCl}_{4}$-induced rise in serum enzymes, the estimated values of ALP, GOT and GPT were $222 \pm 27,114 \pm 23$ and $68 \pm 14 \mathrm{IU} / 1$ respectively. Moreover, it prevented $\mathrm{CCl}_{4}$-induced prolongation in pentobarbital sleeping time which further confirmed hepatoprotectivity [32].

The natural root and root callus extracts of Cichorium intybus were studied for their anti-hepatotoxic effects in Wistar strain of Albino rats against carbon tetrachloride induced hepatic damage. The increased levels of serum enzymes (aspartate transaminase, alanine transaminase) and bilirubin observed in rats treated with carbon tetrachloride were very much reduced in the animals treated with natural root and root callus extracts and carbon tetrachloride. The decreased levels of albumin and proteins observed in rats after treatment with carbon tetrachloride were found to increase in rats treated with natural root and root callus extracts and carbon tetrachloride. These biochemical observations were confirmed by histopathological examination of liver sections [33].

Esculetin, a phenolic compound found in Cichorium intybus was investigated for its possible protective effect against paracetamol and $\mathrm{CCl}_{4}$-induced hepatic damage. Paracetamol produced $100 \%$ mortality at the dose of $1 \mathrm{~g} / \mathrm{kg}$ in mice while pre-treatment of animals with esculetin $(6 \mathrm{mg} / \mathrm{kg})$ reduced the death rate to $40 \%$. Oral administration of paracetamol $(640 \mathrm{mg} / \mathrm{kg})$ produced liver damage in rats as manifested by the rise in serum enzyme levels of alkaline phosphatase (ALP) and aminotransferases (AST and ALT). Pretreatment of rats with esculetin $(6 \mathrm{mg} / \mathrm{kg})$ prevented the paracetamol-induced rise in serum enzymes. The hepatotoxic dose of $\mathrm{CCl}_{4}(1.5 \mathrm{ml} / \mathrm{kg}$; orally) also raised serum ALP, AST and ALT levels. The same dose of esculetin $(6 \mathrm{mg} / \mathrm{kg})$ was able to prevent the $\mathrm{CCl}_{4}$-induced rise in serum enzymes. Esculetin also prevented $\mathrm{CCl}_{4}$-induced prolongation in pentobarbital sleeping time confirming hepatoprotectivity [34].

The hepatoprotective effect of ginger, chicory and their mixture against carbon tetrachloride intoxication was investigated in rats. Carbon tetrachloride treatment significantly elevated the alanine aminotransferase, aspartate aminotransferase, alkaline phosphatase and gamma glutamyltransferase activities and the serum triglycerides and cholesterol concentration as compared to control group. It also increased RBCs counts, $\mathrm{Hb}$ concentration, total and differential leucocytes counts. However it decreased platelet counts, platelet distribution width, mean platelet volume, platelet larger cell ratio. Methanol extract of chicory $(250$ and 500 $\mathrm{mg} / \mathrm{kg})$ alone or mixed with ginger $(250$ and $500 \mathrm{mg} / \mathrm{kg})(1: 1 \mathrm{wt} / \mathrm{wt})$ significantly restored the carbon tetrachloride-induced alterations in the biochemical and cellular constituents of blood. No toxic symptoms were reported in doses up to $5 \mathrm{~g} / \mathrm{kg}[35]$.

The possible potential therapeutic and protective effects of Cichorium intybus (chicory) against oxytetracyclin-induced fatty liver was studied in rats. Fatty liver groups showed high significant increase in serum glucose, cholesterol, triglycerides, LDL cholesterol, ALAT, ASAT, GGT, LDH, urea, creatinine and albumin level to globulin level ratio. Total protein, albumin, globulin and HDL cholesterol were significantly decreased compared to control group. These biochemical changes were accompanied with fatty liver histopathological alterations. The treatment with chicory ameliorated most of the evaluated biochemical parameters and improved the induced degenerative histopathological changes. The pretreatment with chicory before the induction of fatty liver, gave some protection against experimentally induced fatty liver [36].

The hepatoprotective activity of aqueous-ethanolic (30:70\%) extract of fresh dried leaves of Cichorium intybus at the doses of 100, 200 and $300 \mathrm{mg} / \mathrm{kg}$ body weight po, was compared with Silymarin (25 $\mathrm{mg} / \mathrm{kg}$, po) treated animals. The significant changes in biochemical parameters (increases in serum glutamate pyruvate transaminase (SGPT), serum glutamate oxaloacetate transaminase (SGOT), alanine phosphatase (ALP) and serum tolal bilirubin (TB) level) in Nimesulide intoxicated rats, were restored towards normal values in Cichorium intybus leaves extract $(100 \mathrm{mg} / \mathrm{kg}, 200 \mathrm{mg} / \mathrm{kg}$ and $300 \mathrm{mg} / \mathrm{kg}$, po) treated animals. Histopathological examination of liver tissues further substantiated these findings [37].

Cichotyboside isolated from the seeds of Cichorium intybus exhibited a significant anti-hepatotoxic activity against $\mathrm{CCl}_{4}$ induced toxicity in Wistar rats, wherein it reduced the elevated levels of liver enzymes such as serum glutamate oxaloacetate transaminase (SGOT) by 52 units/ml; SGPT 38 units/ml; ALKP 24.97 units $/ \mathrm{ml}$, with $7.54 \mathrm{~g} / \mathrm{dl}, 5.48 \mathrm{~g} / \mathrm{dl}$ increase in total protein and albumin, respectively. It was observed that cichotyboside decreased the level of ALKP comparable with that of standard drug silymarin, exhibiting an $88 \%$ decrease in comparison to silymarin (92\%) and increased the level of total albumin $85 \%$ in comparison to silymarin (89\%) against intoxicated control. Whereas, the levels of SGOT and SGPT were also decreased considerably in comparison to standard and intoxicated control [38].

Cichorium root extract therapy normalized some morphofunctional liver features (decreases glycogen content and necrosis and increases the number of cells with pronounced protein synthesis activity in rats with $\mathrm{CCl}_{4}$-induced hepatitis [39]. 
The effects of Cichorium intybus root extracts at different doses were tested against $\mathrm{CCl}_{4}$ induced rats liver toxicity. The elevated serum markers and liver tissue microvesicular steatosis were significantly reduced in Cichorium intybus groups at $150-450$ or $200-500 \mathrm{mg} / \mathrm{kg} / \mathrm{day}$ [40-41].

The effect of chicory (Cichorium intybus L.) seed extract was evaluated in hepatic steatosis caused by early and late stage diabetes in rats, and induced in HepG2 cells (in vitro) by BSA-oleic acid complex (OA). Different dosages of Cichorium intybus seed extract $(1.25,2.5$ and $5 \mathrm{mg} / \mathrm{ml})$ were applied along with OA (1 $\mathrm{mM}$ ) to HepG2 cells, simultaneously and non-simultaneously; and without OA to ordinary non-steatotic cells. Cellular lipid accumulation and glycerol release, and hepatic triglyceride (TG) content were measured. The expression levels of sterol regulatory element-binding protein-1c (SREBP-1c) and peroxisome proliferatoractivated receptor alpha (PPAR $\alpha$ ) were determined. Significant histological damage (steatosis-inflammationfibrosis) to the cells and tissues and down-regulation of SREBP-1c and PPAR $\alpha$ genes that followed steatosis induction were prevented by Cichorium intybus seed extract in simultaneous treatment. In non-simultaneous treatment, Cichorium intybus seed extract up-regulated the expression of both genes and restored the normal levels of the corresponding proteins; with a greater stimulating effect on PPAR $\alpha$, Cichorium intybus seed extract acted as a PPAR $\alpha$ agonist. Cichorium intybus seed extract released glycerol from HepG2 cells, and targeted the first and the second hit phases of hepatic steatosis [42].

Adding of extracts of Cichorium intybus in the reaction mixture containing calf thymus DNA and free radical generating system protect DNA against oxidative damage to its deoxyribose sugar moiety. The effect was dependent on the concentration of plant extracts. However, the effect of Cichorium intybus was pronounced. The result revealed that the observed hepatoprotective effect of crude Cichorium intybus extract may be due to its ability to suppress the oxidative degradation of DNA in the tissue debris [43-44].

Five intraperitoneal injection of cerulean $(50 \mu \mathrm{g} / \mathrm{kg}$ at $1 \mathrm{~h}$ intervals) in mice resulted in acute pancreatitis, which was characterized by edema, neutrophil infiltration, as well as increases in the serum levels of amylase and lipase in comparison to normal mice. Different doses of Cichorium intybus root (CRE) and aerial parts hydroalcoholic extract (CAPE) orally $(50,100,200 \mathrm{mg} / \mathrm{kg})$ and intraperitoneally $(50,100,200$ $\mathrm{mg} / \mathrm{kg}$ ) were administrated 1.0 and $0.5 \mathrm{~h}$ respectively before pancreatitis induction on separate groups of male mice $(\mathrm{n}=6)$. Control groups treated with normal saline $(5 \mathrm{ml} / \mathrm{kg})$ similarly. Both extracts in greater test doses $(100 \mathrm{mg} / \mathrm{kg}$ and $200 \mathrm{mg} / \mathrm{kg}$, ip) were effective to decrease amylase (23-36\%) and lipase (27-35\%) levels. In oral route, the dose of $200 \mathrm{mg} / \mathrm{kg}$ showed a significant decrease in levels of amylase (16\%) and lipase (24\%) activity while the greatest dose $(200 \mathrm{mg} / \mathrm{kg}$, ip) was only effective to diminish inflammatory features like edema and leukocyte infiltration in pancreatitis tissue $(\mathrm{P}<0.01)$ [45].

\section{Cistanche tubulosa}

The methanolic extract from fresh stems of Cistanche tubulosa possessed hepatoprotective effects against D-galactosamine (D-GalN)/lipopolysaccharide (LPS)-induced liver injury in mice. Among the isolated compounds, echinacoside, acteoside, isoacteoside, acetylacteoside, and tubuloside A, inhibited D-GalNinduced death of hepatocytes. These five compounds, and cistantubuloside B also reduced TNF-alpha-induced cytotoxicity in L929 cells [46].

The hypocholesterolemic effect of the aqueous ethanol extract (CTE) from the roots of Cistanche tubulosa was evaluated using gene chip and RT-PCR analysis of the livers of mice given CTE (400 $\mathrm{mg} / \mathrm{kg}$ ) for 14 days. The administration of CTE $(400 \mathrm{mg} / \mathrm{kg})$ for 14 days significantly suppressed serum cholesterol elevation in high cholesterol diet-fed mice. The mRNA expressions of VLDL receptor and cytochrome P450 SCC were significantly enhanced. In addition, acteoside, a major constituent of CTE, was found to enhance the mRNA expressions of apolipoprotein B, VLDL receptor, and cytochrome P450 SCC in HepG2 hepatocytes [47].

Three among acylated phenylethanoid oligoglycosides isolated from stems of Cistanche tubulosa were found to inhibit D-galactosamine-induced cytotoxicity in primary cultured mouse hepatocytes [48].

\section{Citrullus colocynthis}

The protective effect of methanolic extract of Citrullus colocynthis fruits (MECC) was studied in nitrosodiethylamine induced hepatic damage in male rats. Rats received DEN/PB showed elevated levels of cholesterol $(\mathrm{p}<0.05)$, triglycerides (TG, $\mathrm{p}<0.01)$, free fatty acids (FFA, $\mathrm{p}<0.01$ ), low density lipoprotein (LDL, $\mathrm{p}<0.01$ ), very low density lipoprotein (VLDL, $\mathrm{p}<0.05$ ) and decreased level of high density lipoprotein (HDL), urea and creatinine. Administration of MECC $200,400 \mathrm{mg} / \mathrm{kg}$ to rats orally for 28 days significantly reduced the biochemical alterations induced by DEN/PB [49-50].

The nephropathy protective effect of Citrullus colocynthis fruits extract was studied in streptozotocin induced diabetes in rats. The extract of Citrullus colocynthis fruit was given as $(50 \mathrm{mg} / \mathrm{kg} / \mathrm{day})$ orally for 50 days. Citrullus colocynthis fruits extract caused significant decrease in blood glucose, urea, creatinine, microalbuminuria and uric acid, while, GSH, GPx and SOD were significantly increased in comparison with 
diabetic untreated group. The histopathological findings were coincided with biochemical findings in both diabetic and treated groups. Diabetic kidney showed atrophy of renal curpusle, shrinkage of capillary within increase Bowman's space while, diabetic rat received Citrullus colocynthis fruit extract showed partial protection of glumeruli and appeared nearly normal. The study clearly demonstrated that Citrullus colocynthis fruit exerted protective effects on the kidney functions and tissues. So it may play a role in prevent nephropathy as one of microvascular complications of diabetes mellitus [51].

The protective potentials of Citrullus colocynthis was evaluated against gentamicin induced nephrotoxicity. Toxic doses of gentamicin $(80 \mathrm{mg} / \mathrm{kg} / \mathrm{day}$, i.m.) were administered alone and as co-therapy with the extract of Citrullus colocynthis ( $25 \mathrm{mg} / \mathrm{kg} / \mathrm{day}$, po). Physiological, biochemical and histological examinations were performed to compare the experimental and toxic groups with control group animals. Co-therapy of Citrullus colocynthis with gentamicin protected changes in the body weight, blood urea nitrogen, creatinine clearance, proteins and lactate dehydrogenase excretions. However, a significant rise in serum creatinine and serum uric acid with fall in serum calcium and serum potassium was observed, which were significantly different from control group animals. Necrotic and ruptured tubules were also found abundantly. This study revealed that cotheapy of Citrullus colocynthis with gentamicin for twenty one days, failed to protect renal injury associated by gentamicin in spite of its strong antioxidant properties [52].

\section{Citrus species}

The cytoprotective effects of Citrus aurantifolia was evaluated against Aflatoxin B1 (AFB1)-induced liver injury in rat model. Wistar albino rats were divided into five groups. Group I served as the control. Group II treated with vehicle, dimethyl sulfoxide (DMSO) a single intraperitoneally intraperitoneally on day 5. Group III received AFB1-alone (1mg/Kg body weight) intraperitoneally in DMSO as a single dose on day 5 . Group IV and V received Citrus aurantifolia methanolic extract (MeCA) and Citrus aurantifolia aqueous extract (AqCA) $(500 \mathrm{mg} / \mathrm{Kg}$ body weight, per oral) for 5 days and AFB $1(1 \mathrm{mg} / \mathrm{kg}$ body weight) intraperitoneally in DMSO as a single dose on day 5 . At the end of the $8^{\text {th }}$ day, the livers were collected and used to determine the hepatoprotective activity. Genomic DNA fragmentation was observed by agarose gel electrophoretic pattern in the rat livers. The ultra-structure of the liver cells was studied by electron microscopy. Citrus aurantifolia treatment significantly protected nucleic acid. The treatment was significantly inhibited DNA fragmentation. Nucleus structures were well maintained. The results demonstrate that Citrus aurantifolia has a cytoprotective effect against AFB1-induced liver injury [53].

The ethanol extract of Citrus limon fruits was evaluated for its effects on experimental liver damage induced by carbon tetrachloride. The ethyl acetate soluble fraction of the extract of Citrus limon. fruits was evaluated on HepG2 cell line. The ethanol extract normalized the levels of aspartate aminotransferase, alanine aminotransferase, alkaline phosphatase, and total and direct bilirubin, which were altered due to carbon tetrachloride intoxication in rats. In the liver tissue, treatment significantly raised the levels of antioxidant enzymes superoxide dismutase and catalase. It improved the reduced glutathione (GSH) levels in treated rats in comparison with $\mathrm{CCl}_{4}$-intoxicated rats. In the histopathologic studies, treated animals exhibited restoration of the liver architecture toward normal. Three doses of ethanol extract $(150,300$, and $500 \mathrm{mg} / \mathrm{kg})$ were evaluated. The results obtained were dose dependent, and the effect of the highest dose was almost equal to the standard silymarin. Significant reduction in cell viability was observed in cells exposed to $\mathrm{CCl}_{4}$. A dose-dependent increase in the cell viability was observed when $\mathrm{CCl}_{4}$-exposed $\mathrm{HepG} 2$ cells were treated with different concentrations of ethyl acetate soluble fraction of the ethanol extract. The highest percentage viability of HepG2 cells was observed at a concentration of $100 \mu \mathrm{g} / \mathrm{ml}$ [54].

Ethylene glycol $(0.75 \% \mathrm{v} / \mathrm{v}$ po in drinking water; 28 days) induced urolithiasis was used to study the protective effect of flavanoid rich fraction of Citrus medica (FFCM) at three dose level (320, 380 and 440 $\mu \mathrm{g} / \mathrm{kg}$ - 28 days; po) in male wistar albino rats. Cystone $(750 \mathrm{mg} / \mathrm{kg}$; po) was used as standard drug. After completion of treatment period of 28 days, $24 \mathrm{hr}$ urine sample and blood were collected. Various physical parameters like body weight, diuresis, $\mathrm{pH}$, kidneys weight (wet and dry) were measured. Various stone forming inhibitors (magnesium and citrate) and promoters (oxalate, calcium, phosphate, uric acid and urea) were analysed in urine, serum and kidney homogenate. Renal function test (BUN and creatinine clearance), antioxidant parameters (MDA and catalase) and crystalluria were also evaluated. FFCM at all dose level significantly prevented EG induced changes in calcium, inorganic phosphate, uric acid, oxalate, urea, citrate, magnesium level; creatinine clearance and oxidative stress. FFCM possessed anti-lithiatic activity in experimentally induced urolithiatic model that can be attributed to its diuretic action, decrease in promoters and increase in inhibitors level as well as antioxidant potential [55].

The hepatoprotective activity of orange essential oils was evaluated in carbon tetrachloride-induced hepatotoxicity in rats. Orange essential oils significantly reduced the serum ALT level when compared to $\mathrm{CCl}_{4}$ group, while it did not affect the serum AST level. The histopathological findings did not show any significant difference between the orange essential oils treated and $\mathrm{CCl}_{4}$ groups [56]. 


\section{Clerodendron inerme}

The potential genomic stability and tissue protection of petroleum ether and methanolic extract of Clerodendron inerme (L.) Gaertn leaves were studied using F1 hybrid mice (C57BL male and Swiss albino female). Results revealed that when the Clerodendron inerme methanolic extract (CIME) was given alone and with radiation therapy ( $4 \mathrm{~Gy}$ ), the intestinal tissues were protected better by methanolic extract $500 \mathrm{mg} / \mathrm{kg}$ bw orally in mice as compared to test groups and radiation control group. Methanolic extract showed good results in intestinal tissue protection but the percentage of the chromosomal aberration was not well appreciated in comparison to petroleum ether extract which showed good activity in reducing percentage of chromosomal aberration [57-58].

The etanolic extract of Clerodendron inerme leaves were screened for its hepatoprotective activity in paracetamol induced liver damage in Swiss albino rats at a dose of $200 \mathrm{mg} / \mathrm{kg}$ bw. The ethanolic extract exhibited a significant protective effect by lowering serum levels of glutamic oxaloacetic transaminase, glutamic pyruvic transaminase, alkaline phosphatase and total bilirubin [59].

\section{Clitoria ternatea}

Petroleum ether, chloroform, and methanol extracts of roots of blue and white flowered varieties of Clitoria ternatea (CT) were studied for their hepatoprotective potential against carbon tetrachloride $\left(\mathrm{CCl}_{4}\right)$ induced hepatotoxicity in rats. The hepatoprotective activity was assessed using various biochemical parameters like serum glutamate oxaloacetate transaminase, serum glutamate pyruvate transaminase, serum alkaline phosphatase and total bilirubin along with histopathological studies of liver tissues. The substantially elevated serum enzymatic levels of serum transaminases, alkaline phosphatase and total bilirubin were significantly restored towards normalization with the treatment of CT. The biochemical improvement were confirmed by histopathological examination of liver sections [60-61].

The nephroprotective and antioxidant activities of the ethanol extract of the aerial parts of Clitoria ternatea were evaluated in acetaminophen induced toxicity in rats. Biochemical studies showed that there was an increase in the levels of serum urea and creatinine along with an increase in the body weight and reduction in the levels of uric acid in acetaminophen induced groups. These values were retrieved significantly by treatment with Clitoria ternatea extracts at two different doses. The antioxidant studies reveal that the levels of renal SOD, CAT, GSH and GPx in the APAP treated animals were increased significantly along with a reduced MDA content in Clitoria ternatea ethanol extract treated groups. Histopathological changes also reveal the protective nature of the Clitoria ternatea extract against acetaminophen induced necrotic damage of renal tissues [62].

The protective effect of Clitoria ternatea (CT) flower extracts with antioxidant activity were studied in male reproductive parameters including sperm concentration, serum testosterone level, histopathology of the testis, and testicular tyrosine phosphorylation levels in testicular damage in rats induced with ketoconazole (KET). The antioxidant activity of CT flower extracts was determined using 2,2-diphenyl-1-picrylhydrazyl (DPPH) and ferric reducing antioxidant power (FRAP) assays. Male rats were treated with CT flower extracts $(10,50$, or $100 \mathrm{mg} / \mathrm{kg} \mathrm{BW})$ or distilled water via a gastric tube for 28 days (preventive period: Days 1-21) and testicular damage induced by KET $(100 \mathrm{mg} / \mathrm{kg}$ bw) via intraperitoneal injection for 7 days (induction period: Days 22-28). After the experiment, all animals were examined for the weights of the testis, epididymis, vas deferens and seminal vesicle, serum testosterone levels, sperm concentration, histological structures and diameter of testis, and testicular tyrosine phosphorylation levels by immunoblotting. The CT flower extracts had capabilities for DPPH scavenging and high reducing power. At $100 \mathrm{mg} / \mathrm{kg}$ bw, the extract had no toxic effects on the male reproductive system. Significantly, in CT+KET groups, CT flower extracts (50 and $100 \mathrm{mg} / \mathrm{kg} \mathrm{BW}$ ) alleviated the reduction of reproductive organ weight parameters, testosterone levels, and sperm concentration. In addition, CT flower extracts gave protection from testicular damage in KET-induced rats. Moreover, in the CT100+KET group, CT flower extracts significantly enhanced the expression of a testicular 50-kDa tyrosine phosphorylated protein compared with that of other groups [63].

\section{Convolvulus arvensis}

The hepatoprotective activity of Convolvulus arvensis was studied in paracetamol-induced hepatotoxicity in mice. The results showed that ethanolic extract of Convolvulus arvensis (200 and $500 \mathrm{mg} / \mathrm{kg}$ ) produced significant $(\mathrm{p}<0.05)$ decrease in paracetamol induced increased levels of liver enzymes and total bilirubin. Histopathological investigation supported the hepato-protective effects of Convolvulus arvensis [6465].

\section{Cordia myxa}

The potential protective effects of methanolic extracts of Cordia myxa against doxorubicin (DOX)induced cardiotoxicity was studied in rats. It showed promising cardioprotective potential. Its extracts showed 
potent in vitro radical scavenging and antioxidant properties. It significantly protected against DOX-induced alterations in cardiac oxidative stress markers (GSH and MDA) and cardiac serum markers (CK-MB and LDH activities). Additionally, histopathological examination confirmed the protective effect against DOX-induced cardiotoxicity [66-67].

The hepatoprotective effect of Cordia myxa. (CM) extracts was studied in rats. Oxydative liver damage in rats was induced by two agents, carbon tetrachloride $\left(\mathrm{CCl}_{4}\right)$ and thioacetamide (TA). Oxydative damage was evaluated by a measurement of aspartate transaminase (AST), glutamate transaminase (ALT) and alkaline phosphatase (ALP) in sera of the rats. Several extracts of Cordia myxa were prepared and were fed to experimental animals over a period of two weeks. Liver recovery was assessed by re-measuring the hepatic enzymes and their comparison with the control group. $\mathrm{CCl}_{4}$ and TA induced comparable oxidative liver damage as measured through hepatic enzymes. A significant $(\mathrm{P}=0.05)$ liver recovery was noticed when animals treated with $\mathrm{CCl}_{4} / \mathrm{TA}$ were fed with $\mathrm{CM}$ extracts [68].

The protective role of Cordia myxa (CM) extracts ( 50-500mg/kg) against liver fibrosis induced by carbon tetrachloride or thioacetamide (TA) was investigated in rats. The serum aspartate transaminase (AST), glutamate transaminase (ALT) and alkaline phosphatase (ALP) were significantly improved in rats after administration of $\left(\mathrm{CCl}_{4}\right)+\mathrm{CM}$, or $(\mathrm{TA})+\mathrm{CM}$ as compared to rats treated alone with $\mathrm{CCl}_{4}$ or TA [69].

The influence of Cordia myxa extract on blood picture after administration of a high dose of mefenamic acid (ponstan) was studied in mice. Four groups of mice were used in this experiment, and designated as A, B, C and D. Group A received distilled water and served as control. Group B received plant extract at a dose of $600 \mathrm{mg}$ per $\mathrm{kg}$ bw. Group $\mathrm{C}$ received ponstan at a dose of $100 \mathrm{mg}$ per $\mathrm{kg}$ bw and group D received the half dose of both treatments simultaneously. After 21 days, all mice were euthanized and blood sample from each animal was taken for examination. The right femur bone of each animal was taken to perform histological sections. The extract showed an enhancing effect on some blood parameters both when the plant extract was given alone or simultaneously with ponstan. The plant extract caused disappearance of mild degenerative and other adverse changes resulted from ponstan on bone marrow [70].

\section{Coriandrum sativum}

The radio protective ability of Coriandrum sativum seeds against whole body gamma irradiation was studied in rats. Coriander aqueous extract group (CE) rats received the aqueous extract $300 \mathrm{mg} / \mathrm{kg} \mathrm{bw} /$ day for 42 days. Irradiated group: rats were subjected to whole body gamma irradiation at dose of 4 Gy delivered as a single exposure dose. In combined treatment group, rats received orally CE ( $300 \mathrm{mg} / \mathrm{kg}$ bw/ day) for 42 days, at day 35 of $\mathrm{CE}$ treatment, the rats were irradiated at dose level of $4 \mathrm{~Gy}$. The animals exposed to gamma radiation showed a significant increase in serum aspartate transaminase, alanine transaminase, alkaline phosphatase, lactate dehydrogenase, urea, creatinine, total cholesterol, triglycerides, low density lipoprotein cholesterol and tissue thiobarbituric acid reactive substance. Gamma irradiation caused significant decrease in serum total protein, albumin and high density lipoprotein cholesterol. A decrease of liver and kidney reduced glutathione content, superoxides dismutase and catalase activities were reported. Treatment of rats with CE significantly reduced the radiation-induced serum biochemical disorders which was associated with significant amelioration in the oxidant / antioxidant status of liver and kidney tissues [71].

The administration of paracetamol caused a significant increase in plasma alanine amino transferase, aspartate amino transferase, alkaline phosphates, gamma glutamyl transferase, bilirubin, urea and creatinine with significant decrease in plasma total proteins, albumin and some antioxidant biomarkers (plasma total antioxidant capacity, catalase and glutathione peroxidase) compared to normal rates. Statistical analysis indicated that rats which supplemented with aqueous extract of Coriandrum sativum and then administrated paracetamol showed significant improvement in all biochemical parameters, which become near to control, the results were confirmed by histopathological examination of the liver tissue of control and treated animals [72].

The antioxidant activity of Coriandrum sativum was evaluated in $\mathrm{CCl}_{4}$ treated oxidative stress in rats. $\mathrm{CCl}_{4}$ injection induced oxidative stress by a significant rise in serum marker enzymes and thiobarbituric acid reactive substances (TBARS) along with the reduction of antioxidant enzymes. In serum, the activities of enzymes, ALP, ACP and protein and bilirubin were evaluated. Pretreatment of rats with different doses of plant extract (100 and $200 \mathrm{mg} / \mathrm{kg}$ ) significantly lowered SGOT, SGPT and TBARS levels against $\mathrm{CCl}_{4}$ treated rats. Hepatic enzymes like SOD, CAT, GPx were significantly increased by treatment with plant extract against $\mathrm{CCl}_{4}$ treated rats. Histopathological examinations showed extensive liver injuries, characterized by extensive hepatocellular degeneration/necrosis, inflammatory cell infiltration, congestion, and sinusoidal dilatation in $\mathrm{CCl}_{4}$ trated rats. Oral administration of the leaf extract at a dose of $200 \mathrm{mg} / \mathrm{kg}$ bw significantly reduced the histological effects induced by $\mathrm{CCl}_{4}$. The activity of leaf extract at the dose of $200 \mathrm{mg} / \mathrm{kg}$ was comparable to the standard drug, silymarin [73].

The hepatoprotective activity of Coriandrum sativum against carbon tetrachloride was studied, with estimation of serum glutamyl oxaloacetic acid transaminase, serum glutamyl pyruvate transaminase, alkaine 
phosphatase and bilirubin. Coriandrum sativum possessed hepatoprotection by reducing the liver weight, activities of SGOT, SGPT, and ALP, and direct bilirubin of $\mathrm{CCl}_{4}$ intoxicated animals. These results were confermied be histological effects, administration of Coriandrum sativum extract at $300 \mathrm{mg} / \mathrm{kg}$ dose resulted in disappearance of fatty deposit, ballooning degeneration and necrosis [74].

Essential oils of Coriandrum sativum were assayed for their in vitro and in vivo antioxidant activity and hepatoprotective effect against carbon tetrachloride damage. The in vitro antioxidant activity was evaluated as a free radical scavenging capacity (RSC), measured as scavenging activity of the essential oils on 2,2diphenyl-1-picrylhydrazyl (DPPH) and $\mathrm{OH}$ radicals and effects on lipid peroxidation (LP) in two systems of induction. Liver biochemical parameters were determined in animals pretreated with essential oils and later intoxicated with $\mathrm{CCl}_{4}$ to assess in vivo hepatoprotective effect. The essential oils were able to reduce the stable DPPH in a dose-dependent manner and to neutralize $\mathrm{H}_{2} \mathrm{O}_{2}$, with $\mathrm{IC}_{50}$ values of $4.05 \mathrm{microl} / \mathrm{ml}$ [75].

The effect of coriander seed powder (CSP) on dimethyl hydrazine (DMH)-induced oxidative stress and toxicity in rats was investigated. Rats were maintained on the treatments for 12 weeks. The results revealed that DMH administration lead to an increase in hepatic lipid peroxidation associated with reduction in levels of glutathione (GSH), activity of superoxide dismutase (SOD), catalase, and glucose-6-phosphate dehydrogenase. The coadministration of CSP $10 \%$ and DMH diminished the hepatic malondialdehyde (MDA) significantly as compared to DMH-alone administered rats. The intake of coriander seeds at $10 \%$ level also enhanced the hepatic GSH-redox system by elevating GSH-Px, GSSGR, and GST activities. The DMH-induced decline in SOD and catalase activities was brought to normal by $10 \%$ CSP. The coadministration of CSP and the DMH produced a significant reduction in MDA and enhancement in catalase activity as compared to control. Coriander powder at $5 \%$ and $10 \%$ levels produced a significant rise in colonic catalase and GSH-Px. The coriander seeds produced significant beneficial effects by reducing the DMH-induced oxidative stress and enhancing the tissue levels of antioxidant/detoxification agent in tissues[76].

The preventive effect of ethanol extract of Coriandrum sativum on lead deposition was investigated in male ICR mice given lead (1000 ppm) as lead acetate trihydrate in drinking water for 32 days. Administration of Coriandrum sativum to mice by gastric intubation was performed for 25 days from day 7 after the start of lead exposure up to the end of the experiment. The mice were then sacrificed for comparison of lead distribution. The lead reached its highest concentration in the femur but localized lead deposition in the femur was significantly decreased by meso-2,3-dimercaptosuccinic acid (DMSA), a chelating agent used as a positive control to validate the experimental model. Administration of Coriandrum sativum also significantly decreased lead deposition in the femur and severe lead-induced injury in the kidneys. In addition, urinary excretion of delta-aminolevulinic acid (ALA) which was known to increase with lead intake was significantly decreased after administration of Coriandrum sativum. The $\mathrm{MeOH}$ extract of Coriandrum sativum also reduced leadinduced inhibition of delta-aminolevulinic acid dehydratase (ALAD) activity in vitro [77].

The protective effect of Coriandrum sativum in lead intoxication was studied mice. Oxidative stress was induced in mice by a daily dose of lead nitrate $(40 \mathrm{mg} / \mathrm{kg}$ bw by oral gavage $)$ for seven days. From day eight, experimental animals received an oral dose of coriander extracts (aqueous extract 300 and $600 \mathrm{mg} /$ $\mathrm{kg}$ bw; ethanolic extract 250 and $500 \mathrm{mg} / \mathrm{kg} \mathrm{bw}$ ) along with lead nitrate daily for 40 days. The coriander supplementation to intoxicated mice, protected the weights of experimental animals as compared to lead nitrate exposed untreated animals. Ingestion of $\mathrm{Pb}\left(\mathrm{NO}_{3}\right)_{2}$ was significantly decreased RBC count, WBC count, $\mathrm{Hb}$ level and serum total protein contents in the lead nitrate treated mice. But, serum alanine transaminase, aspartate aminotransferase, creatinine and cholesterol level were significantly increased after implication of this metal. However, oral administration of Coriandrum sativum to lead treated mice led to marked improvement in both hematological and serum biochemical changes. A decrease in viability of neutrophiles, phagocytic index, immunoglobulin level and plaque count were the salient features observed in lead exposed animals. Oral administration of coriander extracts to $\mathrm{Pb}\left(\mathrm{NO}_{3}\right)_{2}$ treated groups attenuated the deranged parameters to some extent [78].

The efficacy of Coriandrum sativum in reducing lead-induced changes in testis was evaluated in mice. Animal exposed to lead nitrate showed significant decrease in testicular SOD, CAT, GSH, and total protein levels. This was accompanied by simultaneous increase in the activities of LPO, AST, ALT, ACP, ALP, and cholesterol level. Serum testosterone level and sperm density were suppressed in lead-treated group compared with the control. These influences of lead were prevented by concurrent daily administration of Coriandrum sativum extracts to some extent. Treating albino mice with lead-induced various histological changes in the testis, while the treatment with coriander led to an improvement in the histological testis picture [79].

The protective activity of the hydroalcoholic extract of Coriandrum sativum seed against lead-induced oxidative stress was studied in rats. Male rats were given $1,000 \mathrm{mg} / \mathrm{L}$ lead acetate for 4 weeks, Coriandrum sativum treatment was given as 250 and $500 \mathrm{mg} / \mathrm{kg}$ bw/day for seven consecutive days after 4 weeks of lead exposure. A significant $(\mathrm{p}<0.05)$ increase in reactive oxygen species, lipid peroxidation products, and total 
protein carbonyl content levels was observed in exposed rat brain regions, while delta-amino levulinic acid dehydratase showed a decrease indicating lead-induced oxidative stress. Treatment with the hydroalcoholic seed extract of Coriandrum sativum resulted in a tissue-specific amelioration of oxidative stress produced by lead [80].

The effect of Coriandrum sativum was studied against lead nitrate induced toxicity in mice. Oxidative stress was induced in mice by a daily dose of lead nitrate $(40 \mathrm{mg} / \mathrm{kg}$ bw by oral gavage) for seven days. From day eight, after lead nitrate treatment, experimental animals received an oral dose of coriander extracts (aqueous extract $300 \mathrm{mg} / \mathrm{kg}$ body weight and $600 \mathrm{mg} / \mathrm{kg}$ bw, ethanolic extract 250 and $500 \mathrm{mg} / \mathrm{kg} \mathrm{bw}$ ) daily. The effect of these treatments in influencing the lead induced changes on hepatic and renal oxidative stress and biochemical changes along with histopathological alterations in soft tissues were studied. The results showed significant increase in liver and kidney LPO levels in animals treated with lead nitrate while the effect was attenuated by the plant extracts. Also, lead caused a significant decrease in antioxidant enzyme activity and this effect was reversed in groups treated with plant extract. Treatment with coriander significantly reduced the adverse effects related to biochemical parameters altered in animals treated with lead and to hepatic and renal oxidative stress. Oral administration of coriander to lead treated mice attenuated the deranged histopathological changes to some extent [81].

\section{Cotoneaster racemiflora}

The radioprotective effect of aqueous as well as alcoholic extracts of the Mann of the plant, against 2 Gy Gamma irradiation, was analyzed using micronucleus assay on bone marrow cells of male mice. Different doses of $250,500,1000 \mathrm{mg} / \mathrm{kg} / \mathrm{bw}$ for aqueous and $3750,7500,15000 \mathrm{mg} / \mathrm{kg} / \mathrm{bw}$ for alcoholic extract were administered (ip), for five constitutive days prior to $2 \mathrm{~Gy}$ gamma irradiation. The result compared with the known radioprotective effect of vitamin E after the same treatment schedule. High frequency of micronucleus was observed in non treated gamma-exposed mice, which represented the clastogenic effect of irradiation. Vitamin E, aqueous and alcoholic extracts treated mice represented a 5.56, 3.32 and 2.1 times decrease in the gamma-induced micronucleus frequency respectively [82].

\section{Crocus sativus}

The protective effect of aqueous saffron extract on neurotoxicity induced by aluminuim chloride $\left(\mathrm{AlCl}_{3}\right)$ was evaluated in mice. Balb/c and C57BL/6 mice were injected with $\mathrm{AlCl}_{3}, 40 \mathrm{mg} / \mathrm{kg} /$ day for 45 days. Each mice strain was divided into four groups: $\mathrm{AlCl}_{3}$ treated group, $\mathrm{AlCl}_{3}$ plus water saffron extract group (administered with saffron extract at $200 \mathrm{mg} / \mathrm{kg}$ bw once a day for 45 days, $\mathrm{AlCl}_{3}$ plus honey syrup group (administered with honey syrup at $500 \mathrm{mg} / \mathrm{kg}$ bw for 45 days). The control group received no treatment. Oxidative stress and antioxidant status were estimated in the brain and differential display was performed for both mice strains to scan the mRNA in the treated and non treated groups. In addition, the up and down regulated genes were isolated, cloned and sequenced. The sequence analysis was performed and compared with the other genes cited on GenBank. The results showed that there was a decrease in the activity of the antioxidant enzymes ( $\mathrm{p} \leq 0.001)$ such as superoxide dismutase, catalase, and glutathione peroxidase in the $\mathrm{AlCl}_{3}$ groups of both mice strains. The level of brain thiobarbituric acid reactive substances showed a significant increase $(\mathrm{p} \leq 0.001)$ of lipid peroxidation in the $\mathrm{AlCl}_{3}$ groups. There was an indication of carcinogenicity in the $\mathrm{AlCl}_{3}$ treated group representing an increase in serum tumor markers such as arginase and a-l-fucosidase. More than 350 band patterns were obtained and about 22 different up-down regulated genes were observed. The sequence analysis of the three selected up-regulated genes revealed that they were similar to B-cell lymphoma 2 (Bcl-2), $\mathrm{R}$-spondin and the inositol polyphosphate 4-phosphatase genes (INPP4B), respectively. The R-spondin gene was up-regulated in all examined animals except the control ones but the other two genes were only induced in the animals treated with $\mathrm{AlCl}_{3}$ and honey syrup. The authors conclude that the biochemical and molecular studies revealed the neurotoxicity of $\mathrm{AlCl}_{3}$ in the brains of mice. In addition, there was an ameliorative change with saffron extract and honey syrup against $\mathrm{AlCl}_{3}$ neurotoxicity. The obtained molecular results suggested that $\mathrm{AlCl}_{3}$ made induction for BCL-W gene, which was an anticancer gene or belonged to the DNA repair system in the brain cells, as well as for R-spondin and inositol polyphosphate 4-phosphatase genes, which helped in cell proliferation [83-84].

The possible reversal effects of saffron against established aluminum (Al)-toxicity was investigated in adult mice. Groups used included Control, Al-treated $(50 \mathrm{mg} \mathrm{AlCl} / 3 / \mathrm{kg} /$ day diluted in the drinking water for 5 weeks) and $\mathrm{Al}+$ saffron (Al-treatment $+60 \mathrm{mg}$ saffron extract $/ \mathrm{kg} /$ day intraperitoneally for the last 6 days). Learning/ memory, the activity of acetylcholinesterase [AChE, salt-(SS)/detergent-soluble(DS) isoforms], butyrylcholinesterase (BuChE, SS/DS isoforms), monoamine oxidase (MAO-A, MAO-B), the levels of lipid peroxidation (MDA) and reduced glutathione (GSH), in whole brain and cerebellum were assessted. Brain Al and crocetin, the main active metabolite of saffron, were determined in brain after intraperitoneal saffron administration by HPLC. Al caused memory impairment, significant decrease of AChE and BuChE activity, 
activation of brain MAO isoforms but inhibition of cerebellar MAO-B, significant elevation of brain MDA and significant reduction of GSH content. Although saffron extract co-administration had no effect on cognitive performance of mice, it reversed significantly the Al-induced changes in MAO activity and the levels of MDA and GSH. AChE activity was further significantly decreased in cerebral tissues of Al+saffron group. The biochemical changes support the neuroprotective potential of saffron under toxicity [85].

The effect of ethanol extract of Crocus sativus was evaluated in the treatment of experimental autoimmune encephalomyelitis (EAE) in C57BL/6 mice. EAE was induced by immunization of 8 week old mice with MOG(35-55) with complete Freunds adjuvant. Therapy with saffron was started on the day of immunization. After daily oral dosage the saffron significantly reduced the clinical symptoms in C57BL/6 mice with EAE. Also, treated mice displayed a delayed disease onset compared with control mice. TAC production was significantly elevated in saffron treated mice. Effect of saffron on serum NO production was not significant. Typical spinal cord leukocyte infiltration was observed in control mice compared with saffron treated mice. The results suggested that saffron was effective in the prevention of symptomatic EAE by inhibition of oxidative stress and leukocyte infiltration to CNS and may be potentially useful for the treatment of multiple sclerosis (MS) [86].

The neuroprotective effect of saffron extract, its active component crocin and gammaglutamylcysteinylglycine (GSH) was studied in glucose-induced neurotoxicity, using PC12 cells as a suitable in vitro model of diabetic neuropathy. Cell viability was quantitated by MTT assay. ROS was measured using DCF-DA by flow cytometry analysis. The result showed that glucose $(13.5$ and $27 \mathrm{mg} / \mathrm{ml})$ reduced the viability of PC12 cells after 4 days. Saffron extract $(5$ and $25 \mathrm{mg} / \mathrm{ml})$, crocin $(10$ and $50 \mathrm{muM})$ and GSH (10 muM) decreased this toxicity. Glucose toxicity was associated with increased ROS production which reduced by saffron, crocin and GSH pretreatment. The results suggested that saffron and its carotenoid crocin could be potentially useful in diabetic neuropathy treatment [87].The preventive effect of the aqueous extract of saffron was studied against diazinon (DZN) -induced rise of several specific inflammation, oxidative stress and neuronal damage in rats. The saffron extract inhibited the effect of DZN on these biomarkers levels [88].

The modifying effects of Crocus sativus (CS) stigma extract on neurobehavioral activities, malondialdehyde (MDA), reduced glutathione (GSH), glutathione peroxidase, glutathione reductase, glutathione S-transferase, superoxide dismutase (SOD), catalase (CAT), and $\mathrm{Na}^{+}, \mathrm{K}^{+}$-ATPase activities, and glutamate (Glu) and aspartate (Asp) content were examined in the middle cerebral artery (MCA) occlusion (MCAO) model of acute cerebral ischemia in rats. The right MCA of male Wistar rats was occluded for 2 hours using intraluminal 4-0 monofilament, and reperfusion was allowed for 22 hours. MCAO caused significant depletion in the contents of GSH and its dependent enzymes, with significant elevation of MDA, Glu, and Asp. The activities of $\mathrm{Na}^{+}, \mathrm{K}^{+}$-ATPase, SOD, and CAT were decreased significantly by MCAO. The neurobehavioral activities (grip strength, spontaneous motor activity, and motor coordination) were also decreased significantly in the MCAO group. All the alterations induced by ischemia were significantly attenuated by pretreatment with CS $(100 \mathrm{mg} / \mathrm{kg}$ of body weight, po) 7 days before the induction of MCAO and correlated well with histopathology by decreasing the neuronal cell death following MCAO and reperfusion [89].

A rat model of chronic cerebral hypoperfusion was used to determine the effect of saffron extract and crocin on vascular cognitive impairment. Male adult Wistar rats were administered different doses of an aqueous solution of crocin or hydroalcohol extract of saffron intraperitoneally (ip), 5 days after permanent occlusion of the common carotid arteries. Spatial learning and memory were assessed in training trials, 711 days after common carotid artery ligation using the Morris water maze. The results showed that the escape latency time was significantly reduced from $24.64 \mathrm{~s}$ in the control group to 8.77 and $10.47 \mathrm{~s}$ by crocin $(25 \mathrm{mg} / \mathrm{kg})$ and saffron extract $(250 \mathrm{mg} / \mathrm{kg})$. The traveled distance to find the platform was also changed from $772 \mathrm{~cm}$ in the control group to 251 and $294 \mathrm{~cm}$ in the crocin $(25 \mathrm{mg} / \mathrm{kg})$ and saffron extract $(250 \mathrm{mg} / \mathrm{kg})$ groups. The percentages of time spent in the target quadrant, in comparison with the control group (24.16\%), was increased to $34.25 \%$ in the crocin $(25 \mathrm{mg} / \mathrm{kg})$ and $34.85 \%$ in the saffron extract $(250 \mathrm{mg} / \mathrm{kg})$ group. Accordingly, saffron extract and crocin improved spatial cognitive abilities following chronic cerebral hypoperfusion, the effect which may be related to the antioxidant effects of these compounds [90].

The ameliorative effect of saffron aqueous extract on hyperglycemia, hyperlipidemia, and oxidative stress was studied in diabetic encephalopathy in streptozotocin induced diabetes mellitus in rats. Saffron at 40 and $80 \mathrm{mg} / \mathrm{kg}$ significantly increased body weight and serum TNF- $\alpha$ and decreased blood glucose levels, glycosylated serum proteins, and serum advanced glycation endproducts (AGEs) levels. Furthermore, significant increase in HDL and decrease $(\mathrm{P}<0.05)$ in cholesterol, triglyceride, and LDL were observed after 28 days of treatment. At the end of experiments, the hippocampus tissue was used for determination of glutathione content (GSH), superoxide dismutase (SOD), and catalase (CAT) activities. Saffron significantly increased GSH, SOD, and CAT in the the hippocampus tissue, but remarkably decreased cognitive deficit, serum TNF- $\alpha$, and induced nitric oxide synthase (iNOS) activity in hippocampus tissue. Accordingly saffron extract reduced 
hyperglycemia and hyperlipidemia risk and also reduced the oxidative stress in diabetic encephalopathy rats [91].

The protective effects of saffron extract and crocin was evaluated in chronic - stress induced oxidative stress damage of the brain, liver and kidneys in rats. Rats were injected with a daily dose of saffron extract (30 $\mathrm{mg} / \mathrm{kg}$, ip) or crocin $(30 \mathrm{mg} / \mathrm{kg}$, ip) during a period of 21 days following chronic restraint stress $(6 \mathrm{~h} / \mathrm{day})$. In order to determine the changes of the oxidative stress parameters following chronic stress, the levels of the lipid peroxidation product, malondialdehyde (MDA), the total antioxidant reactivity (TAR), as well as antioxidant enzyme activities glutathione peroxidase (GPx), glutathione reductase (GR) and superoxide dismutase (SOD) were measured in the brain, liver and kidneys tissues after the end of chronic stress. In the stressed animals that receiving saline, the levels of MDA, and the activities of GPx, GR, and SOD were significantly higher $(\mathrm{P}<0.0001)$ and the TAR capacity was significantly lower than those of the non-stressed animals $(\mathrm{P}<0.0001)$. Both saffron extract and crocin were able to reverse these changes in the stressed animals as compared with the control groups $(\mathrm{P}<0.05)$. These observations indicate that saffron and its active constituent crocin can prevent chronic stress-induced oxidative stress damage of the brain, liver and kidneys [92].

The protective effects of hydroalcoholic extract from Crocus sativus petals (CSP) against Acetaminophen (APAP) -induced hepatotoxicity was evaluated in male rats. Rats were treated with either low dose $(10 \mathrm{mg} / \mathrm{kg})$ or high dose $(20 \mathrm{mg} / \mathrm{kg})$ of CSP before receiving APAP $(600 \mathrm{mg} / \mathrm{kg}$, iv). The APAP treatment resulted in higher levels of alanine aminotransferase (ALT), aspartate aminotransferase (AST), and bilirubin, along with lower total protein and albumin concentration than the control group. The administration of CSP with a dose of $20 \mathrm{mg} / \mathrm{kg}$ resulted in lower levels of AST, ALT and bilirubin, with a significant higher concentration of total protein and albumin. The histopathological results regarding liver pathology, revealed cell swelling, severe inflammation and necrosis in APAP-exposed rats, which was quiet contrasting compared to the control group. The pre-treated rats with low doses of CSP showed hydropic degeneration with mild necrosis in centrilobular areas of the liver, while the same subjects with high doses of CSP appeared to have only mild hepatocyte degeneration. It was appeared that the antioxidant property of CSP resulted in reducing the oxidative stress complications of toxic levels of APAP in intoxicated rats, and $20 \mathrm{mg} / \mathrm{kg}$ of CSP ameliorates APAP-induced acute liver injury in rats [93].

The potential protective effect of saffron ethanol extract (SEE) in a rat model upon hepatic ischemiareperfusion (IR) injury was studied. Caspases 3 and terminal deoxynucleotidyl transferase-mediated dUTP biotin nick end labeling (TUNEL) results showed increased cell death in the IR samples; reversely, minor apoptosis was detected in the SEE/IR group. Pretreatment with SEE significantly restored the content of antioxidant enzymes (SOD and catalase) and remarkably inhibited the intracellular ROS concentration in terms of reducing $\mathrm{p} 47$ phox translocation. Proteome tools revealed that 20 proteins were significantly modulated in protein intensity between IR and SEE/IR groups. Particularly, SEE administration attenuate the carbonylation level of several chaperone proteins [94].

The protective effect of ethanolic extract of Crocus sativus stigma (EECSL.S) was evaluated against rifampin-induced hepatotoxicity in the rats in comparison with standard drug silimarin. Male Wistar rats with were randomly assigned into 5 groups. Group I as normal control received normal saline (10 ml $/ \mathrm{kg})$ and group II as toxicant control received rifampin $(500 \mathrm{mg} / \mathrm{kg})$. Group $\amalg$ as positive control received silymarin plus rifampin $(500 \mathrm{mg} / \mathrm{kg})$ and groups IV and $\mathrm{V}(50 \mathrm{mg} / \mathrm{kg})$ received EECSL.S at 40 and $80 \mathrm{mg} / \mathrm{kg}$ plus rifampin, respectively. All the treatments were given through gavage for 1 month. At the end of experiment, levels of liver function marker enzymes (aspartate aminotransferase, alanine aminotransferase and alkaline phosphatase), total bilirubin, albumin and total proteins were assessed in serum of the rats. In rifampin-treated rats, silymarin and EECSL.S (40 and $80 \mathrm{mg} / \mathrm{kg}$ ) were significantly decreased the levels of serum biomarker of hepathic injury and total bilirubin and elevated the levels of albumin and total proteins. Histopathologically, silymarin and EECSL.S ameliorated rifampin induced hepatic injury [95].Crocin possessed hepatoprotective effects against aflatoxin B1 hapatotoxicity via the reduction of hepatic (AST, ALT, ALP and $\gamma$-GGT) and via its antioxidant activity in rats [96].

The effect of aqueous extract of Crocus sativus stigmas (CSE) and crocin (trans-crocin 4) was examined on methyl methanesulfonate (MMS)-induced DNA damage in multiple mice organs using the comet assay. Adult male NMRI mice in different groups were treated with either physiological saline $(10 \mathrm{ml} / \mathrm{kg}, \mathrm{ip})$, CSE (80 mg/kg, ip), crocin (400 mg/kg, ip), MMS (120 mg/kg, ip), and CSE (5, 20, and $80 \mathrm{mg} / \mathrm{kg}$, ip) $45 \mathrm{~min}$ prior to MMS administration or crocin $(50,200$, and $400 \mathrm{mg} / \mathrm{kg}$, ip) $45 \mathrm{~min}$ prior to MMS administration. Mice were sacrificed about $3 \mathrm{~h}$ after each different treatment, and the alkaline comet assay was used to evaluate the effect of these compounds on DNA damage in different mice organs. A significant increase in the \% tail DNA was seen in nuclei of different organs of MMS-treated mice. In control groups, no significant difference was found in the \% tail DNA between CSE- or crocin-pretreated and saline-pretreated mice. The MMS-induced DNA damage in CSE-pretreated mice $(80 \mathrm{mg} / \mathrm{kg}$ ) was decreased between 2.67-fold (kidney) and 4.48-fold (lung) compared to those of MMS-treated animals alone $(\mathrm{p}<0.001)$. This suppression of DNA damage by CSE 
was found to be depended on the dose, pretreatment with CSE $(5 \mathrm{mg} / \mathrm{Kg}$ ) only reduced DNA damage by $6.97 \%$, $6.57 \%, 7.27 \%$, and $9.90 \%$ in liver, lung, kidney, and spleen, respectively ( $>0.05$ as compared with MMStreated group. Crocin also significantly decreased DNA damage (between 4.69-fold for liver and 6.55-fold for spleen, $400 \mathrm{mg} / \mathrm{Kg}$ ) [97].

The genotoxic potential of anti-tumor drugs limits their efficacy in the treatment of cancers. The chemoprotective potential of saffron against the genotoxicity of three well-known anti-tumor drugs-cisplatin (CIS), cyclophosphamide (CPH) and mitomycin-C (MMC) — was studied using comet assay. Three doses of saffron $(20,40$ and $80 \mathrm{mg} / \mathrm{kg}$ b.w.) were orally administered to mice for five consecutive days prior to the administration of anti-tumor drugs under investigation. Pre-treatment with saffron significantly inhibited antitumor drugs induced cellular DNA damage (strand breaks) as revealed by decreased comet tail length, tail moment and percent DNA in the tail. These findings, suggest a potential role for saffron as an anti-genotoxic, anti-oxidant and chemopreventive agent and could be used as an adjuvant in chemotherapeutic applications [98].

Experiments were carried out to ascertain whether or not saffron (dried stigmas of Crocus sativus L.), exert modulatory effects on the in vivo genotoxicity of cisplatin (CIS), cyclophosphamide (CPH), mitomycin C (MMC) and urethane (URE). Swiss albino mice were pretreated for five consecutive days with three doses (20, 40 and $80 \mathrm{mg} / \mathrm{kg}$ body weight) of the aqueous extract of saffron. Genotoxic effects were assessed in the mouse bone marrow micronucleus test. The results showed that pretreatment with saffron significantly inhibited the genotoxicity of CIS, CPH, MMC and URE. This inhibitory effect was not always dose-dependent. In addition, the hepatic glutathione S-transferase (GST) activity was assessed in the control and treated animals. No significant change in GST activity was observed after pretreatment with saffron alone. Treatment with the genotoxins alone significantly inhibited GST activity [99].

Crocus sativus (CSE) $(250 \mathrm{mg} / \mathrm{kg}$, po) was also effective in preventing acetaldehyde-induced inhibition of LTP in the dentate gyrus of anesthetized rats. These results suggest that CSE can prevent aversive effects induced by ethanol and its metabolite acetaldehyde [100].

The modifying effects of the aqueous extract of saffron (dried stigmas of Crocus sativus) on cisplatin (CIS), cyclophosphamide (CPH), mitomycin-C (MMC) and urethane (URE) induced alterations in lipid peroxidation and antioxidant status were investigated in Swiss albino mice. Three doses of saffron (20, 40 and $80 \mathrm{mg} / \mathrm{kg}$ body weight) were orally administered to mice for 5 consecutive days prior to administration of genotoxins. A significant reduction in the extent of lipid peroxidation with a concomitant increase in the liver enzymatic (SOD, CAT, GST, GPx) and non-enzymatic antioxidants were observed in saffron pretreated animals compared with the genotoxins alone treated animals. However, the modulatory effects were not always dose dependent. Data suggested that saffron may exerted its chemopreventive effects by modulation of lipid peroxidation, antioxidants and detoxification systems [101].

Saffron (dried stigmas of Crocus sativus), was evaluated in the mouse bone marrow micronucleus test for its possible protective effects against chromosomal damage induced by cisplatin (CIS), mitomycin-C (MMC) and urethane (URE). Three doses of saffron $(25,50$ and $100 \mathrm{mg} / \mathrm{kg}$ body weight) were orally administered to mice for five consecutive days prior to administration of genotoxins under investigation. From the results obtained, it was evident that the administration of 50 and $100 \mathrm{mg}$ saffron $/ \mathrm{kg}$ bw significantly inhibited the in vivo genotoxicity of these genotoxins. However, all the three doses of saffron were effective in exerting a protective effect against urethane [102].

It appeared that concurrent administration of Crocus sativus reduced the toxicity of cisplatin in rats. When cisplatin was administered ip for 5 alternate days as $3 \mathrm{mg} / \mathrm{kg}$, Crocus sativus stigmas $(50 \mathrm{mg} / \mathrm{kg})$ significantly reduced blood urea nitrogen (BUN) and serum creatinine levels as well as cisplatin-induced serum total lipids increases. In contrast, the protective agents given together (Cysteine, vitamin E, Crocus sativus and Nigella sativa) with cisplatin led to an even greater decrease in blood glucose than that seen with cisplatin alone. The serum activities of alkaline phosphatase, lactate dehydrogenase, malate dehydrogenase, aspartate aminotransferase and alanine aminotransferase of cisplatin-treated rats were significantly decreased, whereas the activities of glutathione reductase and isocitrate dehydrogenase were significantly increased. Addition of cysteine and vitamin E, Crocus sativus and Nigella sativa in combination with cisplatin partially prevented many changes in the activities of serum enzymes. In cisplatin-treated rats, the liver activities of isocitrate dehydrogenase and aspartate aminotransferase were significantly increased, whereas much greater changes were found in the kidneys, with increased activity of glucose-6-phosphate dehydrogenase and decreased activities of alkaline phosphatase, isocitrate dehydrogenase, malate dehydrogenase, aspartate aminotransferase, alanine aminotransferase, sorbitol dehydrogenase and $\gamma$-glutamyl transferase, as well as a decreased phosphorylation to oxidation ratio in the mitochondria, indicating reduced adenosine triphosphate production. Also, administration of cysteine and vitamin E, Crocus sativus and Nigella sativa together with cisplatin partially reversed many of the kidney enzymes changes induced by cisplatin. Cysteine together with vitamin E, Crocus sativus and Nigella 
sativa tended to protect from cisplatin-induced falls in leucocyte counts, haemoglobin levels and mean osmotic fragility of erythrocytes and also prevented the increase in haematocrit [103-104].

The protective effect of Crocus sativus on gentamicin nephrotoxicity was investigated in rats. Male rats were treated with saffron ( 40 or $80 \mathrm{mg} / \mathrm{k} /$ day) for 10 days, or saffron ( 40 or $80 \mathrm{mg} / \mathrm{kg} / \mathrm{day}$ ) for 10 days and gentamicin $80 \mathrm{mg} / \mathrm{kg} /$ day for five days, starting from day 6 . At the end of treatment, blood samples were taken for measurement of serum creatinine (SCr) and BUN. The left kidney was prepared for histological evaluation and the right kidney for malondialdehyde (MDA) measurement. Gentamicin 80 (mg/k/day) increased SCr, BUN and renal tissue levels of MDA and induced severe histological changes. Saffron at $40 \mathrm{mg} / \mathrm{kg} / \mathrm{day}$ significantly reduced gentamicin-induced increases in BUN and histological scores $(\mathrm{p}<0.05)$. Gentamicin-induced increases in BUN, SCr and MDA and histological injury were significantly reduced by treatment with saffron $80 \mathrm{mg} / \mathrm{k} / \mathrm{d}$ $(\mathrm{p}<0.05, \mathrm{p}<0.001, \mathrm{p}<0.05$, and $\mathrm{p}<0.001$ respectively) [105].

The protective effect of saffron aqueous extracts in the cytogenetic and testicular damage induced by the antiepileptic drug, sodium valporate (SVP) was investigated in albino rats. Animals given SVP and saffron showed an improvement in chromosomal aberrations, mitotic index, DNA damage and testicular alterations caused by SVP. Moreover, MDA decreased and CAT and RAP increased. The authors concluded that the ameliorative effects of saffron extract against SVP-induced cytogenetic and testicular damage in albino rats could be attributed to one or more antioxidant components of saffron [106].

The extract of Crocus sativus stigmas partially prevented the decreases in body weight, hemoglobin levels and leucocyte counts caused by $2 \mathrm{mg} / \mathrm{kg}$ of cisplatin ip for 5 days in mice. Treatment with the Crocus sativus extract also significantly prolonged the life span of cisplatin-treated mice almost three-fold [107].

\section{Crotalaria juncea}

The petroleum ether extract of Crotalaria juncea seed at low and high dose $(100$ and $500 \mathrm{mg} / \mathrm{kg})$ were tested for its efficacy against thioacetamide induced acute hepatic damage in rats. The different groups of rats were administered with thioacetamide $(100 \mathrm{mg} / \mathrm{kg}$, sc). Drug Silymarin $(100 \mathrm{mg} / \mathrm{kg}$,) was used as reference standard. The rats were monitored for biochemical changes of serum glutamate oxaloacetate transaminase, serum glutamate pyruvate transaminase, serum alkaline phosphatase, and bilirubin (total and direct). Activity of antioxidant enzymes such as superoxide dismutase and catalase in liver tissue homogenate and Histopathological changes were observed. According to the results, it was proved that the crotalaria juncea seed extract (CJSE) possessed hepatoprotective potency in a dose dependent manner by reducing the elevated levels of marker enzymes and by increasing the decreased antioxidant enzyme activity [108-109].

\section{Cuminum cyminum}

The effect of Cuminum cyminum (Cumin) on kidney exposed to profenofos was evaluated in female swiss albino mice. The results showed that cumin was effective in normalizing the uric acid and creatinine level [110-111].

Depression in growth, hepatotoxicity and nephrotoxicity were observed in rats that had been given paracetamol at $500 \mathrm{mg} / \mathrm{kg}$ orally for 4 weeks. These findings were accompanied by leucopenia, macrocytic normochromic anemia and alterations of serum aspartate aminotransferase, alanine aminotransferase and alkaline phosphatase activities and concentrations of cholesterol, urea and other serum constituents. Serum bilirubin did not change. In rats given the mixture of paracetamol $500 \mathrm{mg} / \mathrm{kg}$ plus $6 \%$ Cuminum cyminum fruit for 4 weeks, the recovery of paracetamol hepatotoxicity was evidenced by increase in body weight, absence of hepatocellular fatty vacuolation and significant improvement of serbiochemical and hematological parameters [112].

The effects of cumin on sperm quality and testicular tissue was evaluated following experimentally induced copper poisoning (copper sulphate $100 \mathrm{mg} / \mathrm{kg}$ ) in mice. Cuminum cyminum was used at dose of $1 \mathrm{mg} / \mathrm{kg}$. The results showed that sperm concentration, motility and viability in copper group were significantly decreased at weeks 4 and 6 , and severe degenerative changes were observed in testicular tissues in comparison with the control group. In cumin treated group, significant improvement in the sperm count, motility and viability, and normal architecture in most seminiferous tubules with organized epithelium was observed compared to the copper group [113].

\section{Cupressus sempervirens}

The Cupressus sempervirens extract was investigated for its therapeutic effect against $\mathrm{CCl}_{4}$ hepatotoxicity by biochemical (serum total proteins, albumin, urea, creatinine, LDH) and histopathological evaluations. A single intraperitoneal dose of $10 \% \mathrm{CCl}_{4}$ in olive oil ( $1 \mathrm{ml} / \mathrm{kg}$ body weight $)$ was administered to a group of female Wister rats as the injury group. The other group was given $\mathrm{CCl}_{4}$ and administered with Cupressus sempervirens extract three times per week for six weeks and a further group administered $\mathrm{CCl}_{4}$ was left for six weeks to allow self-recovery. At the end of experiment, the rats from all groups were sacrificed for 
sampling for biochemical and histological analysis. Remarkable disturbances were observed in the levels of all tested parameters. On the other hand, rats injected with the toxic agent and left for one and a half month to self recover showed moderate improvements in the studied parameters. Treatment with herbal extract ameliorated the levels of the disturbed biochemical parameters. The Cupressus sempervirens group also showed histopathological liver \& kidney profiles close to those of the control group [114-115].

Pre-treatment with either hydroethanolic extract $(250 \mathrm{mg} / \mathrm{kg} / \mathrm{day}$, po) or silymarin $(50 \mathrm{mg} / \mathrm{kg} / \mathrm{day}$, po) for 4 weeks has good safety profile in normal rats and exhibited a marked hepatoprotection against single toxic dose of paracetamol (4 g/.kg bw, po) as proved from marked decline in the DNA fragmentations and inhibition in the percentage of chromosomal aberrations in bone marrow cells [116].

The possible protective effect of Cupressus sempervirens and its flavonoids (quercetin and rutin) against the toxicological effect of lead acetate to the liver was evaluated. 30 Male albino rats and divided into five groups (six per group). Group I, served as control, group II exposed to $0.5 \mathrm{mg} / \mathrm{g}$ concentrations of lead acetate in diet for 60 days. Group III was received daily doses of $8 \mathrm{mg} / 100 \mathrm{~g}$ bw of Cupressus sempervirens (liophilized from methanol extract of seeds) two weeks prior to lead acetate administration. Group IV received daily doses of $0.3 \mathrm{mg} / 100 \mathrm{~g}$ bw of the flavonoid quercetin two weeks prior to lead acetate administration; Group $\mathrm{V}$ was received daily doses of $0.1 \mathrm{mg} / 100 \mathrm{~g}$ bw of the flavonoid rutin two weeks prior to lead acetate administration. Lead acetate caused a significant increase in serum and tissue AST, ALT, ALP, bilirubin, serum and tissue MDA, plasma and tissue NO, in addition to, highly significant increase in serum cholesterol, LDL, triglycerides and HDL. On the contrary, lead induced a significant decrease in serum and tissue total protein, albumin, globulin, albumin/globulin ratio, blood and tissue SOD and GPx compared to control group. Administration of Cupressus sempervirens methanol extract, quercetin and rutin two weeks prior to lead acetate prevented the elevation of these parameters. Accordingly, the treatment with Cupressus sempervirens methanol extract and its flavonoids may provide a partial protection against the toxic effect induced by lead acetate [117].

\section{Cuscuta planiflora}

The in vivo hepatoprotective activity of methanolic extract of whole plant was studied in carbon tetrachloride $\left(\mathrm{CCl}_{4}\right)$ induced hepatotoxicity animal model using albino rats. The results showed that, the methanolic extract exerted significant hepatoprotective activity against $\mathrm{CCl}_{4}$ induced hepatotoxicity by suppressing $\mathrm{CCl}_{4}$ induced cellular oxidative stress. Furthermore, these results confirmed by enzymatic and histological study [118].

\section{Cydonia oblonga}

The putative role of quince (Cydonia oblonga) leaf extract in protection and/or alleviation of the negative impacts of UVA on some biochemical and hematological variables was studied in economically important African catfish. A significant $(\mathrm{P}<0.05)$ decrease in the red blood cell counts, hemoglobin and hematocrit were recorded in the groups exposed to UVA compared to the control groups. Exposure to UVA induced marked red cell shrinkage (increased mean cell hemoglobin concentration) and showed an elevation in mean cell volume and mean cell hemoglobin in the blood of the exposed fish compared to the control. A significant $(\mathrm{P}<0.05)$ reduction in the total white blood cells was also recorded in the exposed fish compared to the control. The biochemical parameters (blood glucose, total plasma protein, blood cholesterol, plasma creatinine, aspartic amino transferase and alanine amino transferase) were also exhibited a significant increase in the blood of fish exposed to UVA. Methanolic extract of quince leaf before ripening of the fruits had the ability to prevent hematotoxic stress induced by UVA and resulted in enhancement of the immune system of catfish represented by significant $(\mathrm{P}<0.05)$ increase in the number of white blood cells and lymphocytes of the catfish. Quince extract also protected the red blood cells and biochemical parameters from UVA effects [119120].

The efficacy of quince extracts (Cydonia oblonga) against hyperlipidemia-induced renal injury was studied in rabbits fed on a cholesterol-rich diet with and without a quince leaf extract supplement. Mild glomerular injury and moderate tubular damage were apparent in all rabbits in diseased untreated group, while only milder tubular injury was detected in all animals in groups treated by quince extracts [121].

\section{Cymbopogon schoenanthus}

The preventive potential of ethanol extract of Cymbopogon schoenanthus (CSEE) was studied against stress disorders at in vitro and in vivo levels. It was evaluated in $\mathrm{H}_{2} \mathrm{O}_{2}$-induced cytotoxicity in mice and stress in human neuroblastoma SH-SY5Y cells. Daily oral administration of $100 \mathrm{mg} / \mathrm{kg}$ and $200 \mathrm{mg} / \mathrm{kg}$ CSEE was conducted to mice for 2 weeks. It was resulted in a significant decrease of immobility time in forced swimming and tail suspension tests. The effect of CSEE on animal behavior was concordant with a significant regulation of blood serum corticosterone and cerebral cortex levels of catecholamine (dopamine, adrenaline, and noradrenaline). The results also demonstrated that pretreatment of neuroblastoma SH-SY5Y cells with CSEE at 
Detoxification capacity and protective effects of medicinal plants (part 2): plant based review

$1 / 2000,1 / 1000$, and $1 / 500 \mathrm{v} / \mathrm{v}$ dilutions, significantly inversed $\mathrm{H}_{2} \mathrm{O}_{2}$-induced neurotoxicity. Moreover, CSEE treatments significantly reversed heat shock protein expression in heat-stressed HSP47-transformed cells $\left(42{ }^{\circ} \mathrm{C}\right.$, for $90 \mathrm{~min}$ ) and mRNA expression of HSP27 and HSP90 in $\mathrm{H}_{2} \mathrm{O}_{2}$-treated SH-SY5Y [122].

The effects of Cymbopogon schoenanthus was investigated in experimental induced kidney stones in male Wistar albino rats. Oxalate nephrotoxicity was experimentally induced by $200 \mathrm{mg}$ single dose of glycolic acid given orally (gavage). The rats were divided into three groups: positive control (glycolic acid), test (glycolic acid plus Cymbopogon schoenanthus), and negative control (drinking water). Urine analysis of blood urea nitrogen (BUN), creatinine, and calcium revealed significant differences in induction groeup compared to control. In addition, significant pathological changes were found in the kidney revealed by histopathological studies. Daily oral treatment with the Cymbopogon schoenanthus $(1 \mathrm{ml}$ of the extract) significantly corrected the incidence of nephrotoxicity (BUN, creatinine and calcium level differences). Moreover, a highly potent diuretic activity was recorded for Cymbopogon schoenanthus. After three days of experiments, five treated rats with the glycolic acid only died. The rest of animal survived and looked healthy. The author concluded that the Cymbopogon scheonanthus extract has prophylactic effect in oxalate stone formation [123].

\section{Cynodon dactylon}

The effect of Cynodon dactylon in restoration of the male reproductive dysfunction induced by immobilization stress, was studied by evaluation sexual behavioral, sexual performance, fructose content of the seminal vesicles, epididymal sperm concentration and histopathological examinations. Treatment of rats under stress with methanolic extract of Cynodon dactylon has shown a promising effect in overcoming stress-induced sexual dysfunction, sexual performance, fructose content, sperm concentration and its effect on accessory sexual organs and body weight. The authors concluded that Cynodon dactylon methanolic extract had a potent aphrodisiac and male fertility activity [124].

The methanolic extract of roots of Cynodon dactylon was screened for its hepato-protective activity in diethyl nitrosamine (DEN) induced liver cancer in Swiss albino mice. The plant extract at a dose of $50 \mathrm{mg} / \mathrm{kg}$ was administered orally once a week, up to 30 days after DEN administration. Diethyl nitrosamine treated group showed low significant elevation $(p<0.05)$ in liver GST activity with respect to control, whereas the control, DEN + Cynodon dactylon, DEN + tamoxifen treated animals did not shown any alteration. A highly significant $(p<0.01)$ elevation in GPx activity was observed in DEN treated mice, whereas DEN + Cynodon dactylon showed low significant alteration, while saline and DEN + tamoxifen treated animals did not show any significant alteration. DEN, DEN + Cynodon dactylon showed low significant depletion $(p<0.05)$ in liver CAT activity with respect to control, whereas saline and DEN + Tamoxifen treated animals did not showed any significant alteration [125].

The hepatoprotective activity of roots of Cynodon dactylon in $\mathrm{CCl}_{4}$ induced hepatotoxicity was studied in albino rabbits. Alcoholic extracts of roots of Cynodon dactylon was administered orally for 20 days in a doses of $100 \mathrm{mg} / \mathrm{kg} / \mathrm{day}$. Cynodon dactylon extract was able to bring down the level of serum transaminase, serum alkaline phosphatase, serum bilirubin and increased in serum albumin significantly $(\mathrm{p}<0.001)$, when compared with untreated group [126].

The neuroprotective effects of the aqueous extract of Cynodon dactylon (AECD) was investigated in aluminium-induced neurotoxicity in rats. Male albino rats were administered with $\mathrm{AlCl}_{3}$ at a dose of $4.2 \mathrm{mg} / \mathrm{kg} / \mathrm{day}$ ip for 4 weeks. Experimental rats were given Cynodon dactylon extract in two different doses of $300 \mathrm{mg}$ and $750 \mathrm{mg} / \mathrm{keg} / \mathrm{day}$ orally $1 \mathrm{~h}$ prior to the $\mathrm{AlCl}_{3}$ administration for 4 weeks. At the end of the experiments, antioxidant status and activities of ATPases in cerebral cortex, hippocampus and cerebellum of rat brain were measured. Aluminium administration significantly decreased the level of GSH and the activities of SOD, GPx, GST, $\mathrm{Na}^{+} / \mathrm{K}^{+}$ATPase, and $\mathrm{Mg}^{2+}$ ATPase and increased the level of lipid peroxidation (LPO) in all the brain regions when compared with control rats. Pre-treatment with AECD at a dose of $750 \mathrm{mg} / \mathrm{kg}$ bw increased the antioxidant status and activities of membrane-bound enzymes $\mathrm{Na}^{+} / \mathrm{K}^{+}$ATPase, and $\mathrm{Mg}^{2+}$ ATPase and also decreased the level of LPO significantly, when compared with aluminium-induced neurotoxicity group [127].

The effect of hydroalcoholic extract of Cynodon dactylon was evaluated in ethylene glycol-induced nephrolithiasis in a rat model. Cynodon dactylon extract reduced the levels of calcium oxalate deposition especially in medullary and papillary sections from of the kidney of the treated rats [128].

The beneficial effect of different fractions of Cynodon dactylon was studied in ethylene glycolinduced kidney calculi in rats. Male Wistar rats were randomly divided into control, ethylene glycol, curative, and preventive groups. The control group received tap drinking water for 35 days. Ethylene glycol, curative, and preventive groups received $1 \%$ ethylene glycol for induction of calcium oxalate $(\mathrm{CaOx})$ calculus. Preventive and curative subjects also received different fractions of Cynodon dactylon extract in drinking water at $12.8 \mathrm{mg} / \mathrm{kg}$, since day 0 and day 14 , respectively. After 35 days, the kidneys were removed and examined for histopathological findings and counting the $\mathrm{CaOx}$ deposits in 50 microscopic fields. In curative protocol, 
treatment of rats with Cynodon dactylon n-butanol fraction, significantly reduced the number of the kidney $\mathrm{CaOx}$ deposits compared to ethylene glycol group. In preventive protocol, treatment of rats with Cynodon dactylon ethyl acetate fraction significantly decreased the number of $\mathrm{CaOx}$ deposits compared to ethylene glycol group [129-130].

\section{Cyperus rotuntdus}

The effects of Cyperus rotundus rhizome on cellular lipogenesis and non-alcoholic/diet-induced fatty liver disease, and the molecular mechanism of these actions were studied. It appeared that the hexane fraction of Cyperus rotundus rhizome reduced the elevated transcription levels of sterol regulatory element binding protein-1c (SREBP-1c) in primary hepatocytes following exposure to the liver X receptor $\alpha$ (LXR $\alpha$ ) agonist. The SREBP-1c gene was a master regulator of lipogenesis and a key target of LXR $\alpha$. CRHF inhibited not only the LXR $\alpha$-dependent activation of the synthetic LXR response element (LXRE) promoter, but also the activation of the natural SREBP-1c promoter. Moreover, the hexane fraction of Cyperus rotundus decreased (i) the recruitment of RNA polymerase II to the LXRE of the SREBP-1c gene; (ii) the LXR $\alpha$-dependent upregulation of various lipogenic genes; and (iii) the LXR $\alpha$-mediated accumulation of triglycerides in primary hepatocytes. Furthermore, the hexane fraction of Cyperus rotundus ameliorated fatty liver disease and reduced the expression levels of hepatic lipogenic genes in high sucrose diet (HSD)-fed mice. CRHF did not affect the expression of ATP-binding cassette transporter A1, another important LXR target gene that was required for reverse cholesterol transport (RCT) and protected against atherosclerosis. Accordingly, these results suggested that the hexane fraction of Cyperus rotundus might be a novel therapeutic remedy for fatty liver disease through the selective inhibition of the lipogenic pathway [131-132].

The neuroprotective effects of a water extract of Cyperus rotundus rhizoma against 6hydroxydopamine (6-OHDA)-induced neuronal damage were evaluated in an experimental model of Parkinsons disease. In PC12 cells, water extract of Cyperus rotundus rhizoma showed a significant protective effect on cell viability at 50 and $100 \mathrm{microg} / \mathrm{ml}$. Water extract of Cyperus rotundus rhizoma inhibited generation of reactive oxygen species and nitric oxide, reduction of mitochondrial membrane potential, and caspase-3 activity, which were induced by 6-OHDA. Water extract of Cyperus rotundus rhizoma also showed a significant protective effect against damage to dopaminergic neurons in primary mesencephalic culture [133].

The possible neuroprotective effects of the ethanol extract of Cyperus rotundus on a model of global transient ischemia in rat was investigated by evaluating the pathophysiology of the hippocampal tissue and spatial memory. The group treated with the ethanol extract of Cyperus rotundus $(100 \mathrm{mg} / \mathrm{kg} / \mathrm{day})$ was gavaged from 4 days before, to 3 days after ischemia. Morris water maze test was performed 1 week after ischemia for 4 days. Brain tissue was prepared for Nissl staining. Data showed no statistical difference between the treatment and ischemia groups in water maze task. So, treatment of ischemia with the ethanol extract of Cyperus rotundus cannot improve spatial learning and memory. On the contrary the ethanol extract of Cyperus rotundus ameliorated the CA1 pyramidal cell loss due to transient global ischemia/reperfusion injury [134].

The neuroprotective effect of total oligomeric flavonoids (TOFs), prepared from Cyperus rotundus, was studied in rat model of cerebral ischemia and reperfusion. Male Sprague Dawley rats were subjected to middle cerebral artery occlusion (MCAO) for $2 \mathrm{~h}$ and reperfusion for $70 \mathrm{~h}$. Experimental animals were divided into four groups: Group I - sham operated; Group II - vehicle treated ischemic-reperfusion (IR), and Group III and IV - TOFs treated (100 and $200 \mathrm{mg} / \mathrm{kg}$ body weight, po, respectively). Vehicle or TOFs were pretreated for four days before the induction of ischemia and continued for next three days after the ischemia i.e. treatment was scheduled totally for a period of 7 days. MCAO surgery was performed on day $4,1 \mathrm{~h}$ after TOFs administration. Neuroprotective effect of TOFs was substantiated in terms of neurological deficits, excitotoxicity (glutamate, glutamine synthetase and $\mathrm{Na}^{+}-\mathrm{K}^{+}$-ATPase levels), oxidative stress (malondialdehyde, super oxide dismutase, and glutathione) and neurobehavioral functions in the experimental animals. TOFs decreased glutamate, glutamine synthetase (GS) and increased $\mathrm{Na}^{+}-\mathrm{K}^{+}$-ATPase activity in a dose dependent manner when compared to the IR rats. Treatment with TOFs significantly reduced the neurological deficits and reversed the anxiogenic behavior in rats. Furthermore, it also significantly decreased MDA and increased superoxide dismutase (SOD) and glutathione content in brains of experimental rats. Histopathological examination using cresyl violet staining revealed the attenuation of neuronal loss by TOFs in stroke rats [135].

The protective effect of 200 and $400 \mathrm{mg} / \mathrm{kg}$ of ethanol extract of Cyperus rotundus against sodium nitrite-induced hypoxia injury in rats was evaluated by assessing the cognitive functions, motor, and behavioral effects of ethanol extract of Cyperus rotundus treatment along with the histological changes in the brain. Ethanol extract of Cyperus rotundus at doses of 200 and $400 \mathrm{mg} / \mathrm{kg}$ was able to protect against the cognitive impairments, and the locomotor activity and muscular coordination defects, which were affected by sodium nitrite-induced hypoxia injury in rats [136]. The protective effects of Cyperus rotundus rhizome extract were evaluated through its oxido-nitrosative and anti apoptotic mechanism to attenuate 
peroxynitrite $\left(\mathrm{ONOO}^{-}\right)$induced neurotoxicity, using humanneuroblastoma SH-SY5Y cells. The results elucidate that pre-treatment of neurons with Cyperus rotundus rhizome extract ameliorates the mitochondrial and plasma membrane damage induced by $500 \mu \mathrm{M}$ SIN-1 to $80 \%$ and $24 \%$ as evidenced by MTT and LDH assays. CRE inhibited NO generation by down-regulating i-NOS expression. SIN-1 induced depletion of antioxidant enzyme status was also replenished by Cyperus rotundus rhizome extract which was confirmed by immunoblot analysis of SOD and CAT. The Cyperus rotundus rhizome extract pre-treatment efficiently potentiated the SIN-1 induced apoptotic biomarkers such as bcl-2 and caspase-3 which orchestrate the proteolytic damage of the cell. The $\mathrm{ONOO}^{-}$induced damage to cellular, nuclear and mitochondrial integrity was also restored by Cyperus rotundus rhizome extract. Furthermore, Cyperus rotundus rhizome extract pretreatment also regulated the 3-NT formation which revealed the potential of plant extract against tyrosine nitration [137].

\section{CONCLUSION}

The paper reviewed the hepato- and nephro-protective e effects of the medicinal plants to be used for neutralization and detoxification of the toxic effects of drugs and poisons and to open the door for further phytochemical analysis and clinical trials.

\section{REFERENCES}

[1]. Myo clinic, Nutrition and healthy eating, http://www.mayoclinic.org/healthy-lifestyle/nutrition-andhealthy-eating/expert-answers/detox-diets/faq-20058040

[2]. Al-Snafi AE. The pharmacological and therapeutic importance of Agrimonia eupatoria- A review. Asian Journal of Pharmaceutical Science and Technology 2015; 5(2): 112-117.

[3]. Al-Snafi AE. Alhagi maurorum as a potential medicinal herb: An Overview. International Journal of Pharmacy Review and Research 2015; 5(2):130-136.

[4]. Al-Snafi AE. Pharmacological effects of Allium species grown in Iraq. An overview. International Journal of Pharmaceutical and health care Research 2013;1(4):132-147.

[5]. Al-Snafi AE. The pharmacological activities of Alpinia galangal - A review. International Journal for Pharmaceutical Research Scholars 2014; 3(1-1): 607-614.

[6]. Al-Snafi AE. The pharmacology of Anchusa italica and Anchusa strigosa - A review. International Journal of Pharmacy and Pharmaceutical Sciences 2014; 6(4): 7-10.

[7]. Al-Snafi AE. The Pharmacological importance and chemical constituents of Arctium Lappa. A review. International Journal for Pharmaceutical Research Scholars 2014; 3(1-1): 663-670.

[8]. Al-Snafi AE. The pharmacological importance of Artemisia campestris- A review. Asian Journal of Pharmaceutical Research 2015;5(2): 88-92.

[9]. Al-Snafi AE. The pharmacological importance of Asparagus officinalis - A review. Journal of Pharmaceutical Biology 2015; 5(2): 93-98.

[10]. Al-Snafi AE. Chemical constituents and pharmacological effects of Astragalus hamosus and Astragalus tribuloides grown in Iraq. Asian J of Pharm Sci \& Tech 2015; 5(4): 321-328.

[11]. Al-Snafi AE. The Pharmacological importance of Bauhinia variegata. A Review. International Journal of Pharma Sciences and Research 2013; 4(12): 160-164.

[12]. Al-Snafi AE. The Pharmacological Importance of Benincasa hispida. A review. Int Journal of Pharma Sciences and Research 2013; 4(12): 165-170.

[13]. Al-Snafi AE. The pharmacological importance of Brassica nigra and Brassica rapa grown in Iraq. $\mathrm{J}$ of Pharm Biology 2015; 5(4): 240-253.

[14]. 14-Al-Snafi AE. Therapeutic properties of medicinal plants: a review of their detoxification capacity and protective effects (part 1). Asian Journal of Pharmaceutical Science \& Technology 2015; 5(4): 257-270.

[15]. Al-Snafi AE. The Chemical constituents and pharmacological effects of Bryophyllum calycinum. A review. Journal of Pharma Sciences and Research 2013; 4(12): 171-176.

[16]. Al-Snafi AE. Pharmacology and medicinal properties of Caesalpinia crista - An overview. International Journal of Pharmacy 2015; 5(2): 71-83.

[17]. Al-Snafi AE. The chemical constituents and pharmacological effects of Calendula officinalis - A review. Indian Journal of Pharmaceutical Science \& Research 2015; 5(3): 172-185.

[18]. Al-Snafi AE. The constituents and pharmacological properties of Calotropis procera - An Overview. International Journal of Pharmacy Review \& Research 2015; 5(3): 259-275.

[19]. Al-Snafi AE. Bioactive components and pharmacological effects of Canna indica- An Overview. International Journal of Pharmacology and toxicology 2015; 5(2):71-75.

[20]. Al-Snafi AE. The chemical constituents and pharmacological effects of Capparis spinosa - An overview. Indian Journal of Pharmaceutical Science and Research 2015; 5(2): 93-100. 
[21]. Al-Snafi AE. The chemical constituents and pharmacological effects of Capsella bursa-pastoris - A review. International Journal of Pharmacology and toxicology 2015; 5(2):76-81.

[22]. Al-Snafi AE. The pharmacological importance of Capsicum species (Capsicum annuum and Capsicum frutescens) grown in Iraq. Journal of Pharmaceutical Biology 2015; 5(3): 124-142.

[23]. Al-Snafi AE. The chemical constituents and pharmacological importance of Carthamus tinctorius - An overview. Journal of Pharmaceutical Biology 2015; 5(3): 143-166.

[24]. Al-Snafi AE. The chemical constituents and pharmacological effects of Carum carvi - A review. Indian Journal of Pharmaceutical Science and Research 2015; 5(2): 72-82.

[25]. Al-Snafi AE. The therapeutic importance of Cassia occidentalis - An overview. Indian Journal of Pharmaceutical Science \& Research 2015; 5 (3): 158-171.

[26]. Al-Snafi AE. The pharmacological importance of Casuarina equisetifolia - An Overview. International Journal of Pharmacological Screening Methods 2015; 5(1): 4-9.

[27]. Al-Snafi AE. The chemical constituents and pharmacological importance of Celosia cristata - A review. J of Pharm Biology 2015; 5(4): 254-261.

[28]. Al-Snafi AE. The chemical constituents and pharmacological effects of Chenopodium album - An overview. International J of Pharmacological Screening Methods 2015; 5(1): 10-17.

[29]. Al-Snafi AE. Clinically tested medicinal plant: A review (Part 1). SMU Medical Journal 2016; 3(1): 99128.

[30]. Ramachandra MS, Rao AS and Rani SS. Hepatoprotective and antioxidant activities of areal parts ( except fruits) of Cicer arietinum against carbon tetrachloride induced hepatotoxicity in rats. Int J Pharm 2014; 4(1): 431-436.

[31]. Al-Snafi AE. The medical Importance of Cicer arietinum - A review IOSR Journal of Pharmacy 2016; 6(3): $29-40$.

[32]. Gilani AH and Janbaz KH. Evaluation of the liver protective potential of Cichorium intybus seed extract on acetaminophen and $\mathrm{CCl}_{4}$-induced damage. Phytomedicine 1994;1(3):193-197.

[33]. Zafar R and Mujahid Ali S. Anti-hepatotoxic effects of root and root callus extracts of Cichorium intybus L. J Ethnopharmacol 1998;63(3):227-231.

[34]. Gilani AH, Janbaz $\mathrm{KH}$ and Shah BH. Esculetin prevents liver damage induced by paracetamol and $\mathrm{CCl}_{4}$. Pharmacol Res 1998; 37(1):31-35.

[35]. 35-Atta AH, Elkoly TA, Mouneir SM, Kamel G, Alwabel NA and Zaher S. Hepatoprotective effect of methanol extracts of Zingiber officinale and Cichorium intybus. Indian J Pharm Sci 2010;72(5):564-570.

[36]. 36-Helal EGE, Abd El-Wahab S, Sharaf AMM and Zedan G. Effect of Cichorium intybus L. on fatty liver induced by oxytetracycline in albino rats. The Egyptian Journal of Hospital Medicine 2011; 45: $522-535$.

[37]. Mushtaq A, Ahmad M and Jabeen Q. Pharmacological role of Cichorium intybus as a hepatoprotective agent on the elevated serum marker enzymes level in albino rats intoxicated with nimesulide. Int J Curr Pharm Res 2013; 5(3): 25-30.

[38]. Ahmed B, Khan S, Masood MH and Siddique AH. Anti-hepatotoxic activity of cichotyboside, a sesquiterpene glycoside from the seeds of Cichorium intybus. J Asian Nat Prod Res 2008;10(3-4):223231.

[39]. Krylova SG, Efimova LA, Vymiatina ZK and Zueva EP. The effect of cichorium root extract on the morphofunctional state of liver in rats with carbon tetrachloride induced hepatitis model. Eksp Klin Farmakol 2006;69(6):34-36.

[40]. Fallah Huseini H, Mahmoudabady Z, Ziai SA, Mehrazma M, Alavian SM, Mehdizadeh $M$ and RadjabianT. The Effects of Cynara scolymus L. leaf and Cichorium intybus L. root extracts on carbon tetrachloride induced liver toxicity in rats. Journal of Medicinal Plants 2011; 10 (37): 33-40.

[41]. Heibatollah S, Reza NM; Izadpanah G and Sohailla S. Hepatoprotective effect of Cichorium intybus on $\mathrm{CCl}_{4}$ - induced liver damage in rats. African Journal of Biochemistry Research 2008;2 (6): 141-144.

[42]. Ziamajidi N, Khaghani S, Hassanzadeh G, Vardasbi S, Ahmadian S, Nowrouzi A, Ghaffari SM and Abdirad A. Amelioration by chicory seed extract of diabetes- and oleic acid-induced non-alcoholic fatty liver disease (NAFLD)/non-alcoholic steatohepatitis (NASH) via modulation of PPAR $\alpha$ and SREBP-1. Food Chem Toxicol 2013;58:198-209.

[43]. Sultana S, Perwaiz S, Iqbal M and Athar M. Crude extracts of hepatoprotective plants, Solanum nigrum and Cichorium intybus inhibit free radical-mediated DNA damage. J Ethnopharmacol 1995;45(3):189192.

[44]. Al-Snafi AE. Medical importance of Cichorium intybus - A review IOSR Journal of Pharmacy 2016; 6(3): 41-56.

[45]. Minaiyan M, Ghannadi AR, Mahzouni P and Abed AR. Preventive effect of Cichorium intybus L. two extracts on cerulein-induced acute pancreatitisin mice. Int J Prev Med 2012;3(5):351-357. 
[46]. Morikawa T, Pan Y, Ninomiya K, Imura K, Matsuda H, Yoshikawa M, Yuan D and Muraoka O. Acylated phenylethanoid oligoglycosides with hepatoprotective activity from the desert plant Cistanche tubulosa. Bioorg Med Chem 2010; 18(5):1882-1890.

[47]. Health supplement herbal food Memoregain, http://www.taiwantrade.com.tw/EP/ sinphar/ productsdetail/en-US/520667/Health-Supplement-herbal-food- Memoregain/

[48]. Pan Y, Morikawa T, Ninomiya K, Imura K, Yuan D, Yoshikawa M and Muraoka O. Bioactive constituents from chinese natural medicines. XXXVI. Four new acylated phenylethanoid oligoglycosides, kankanosides J1, J2, K1, and K2, from stems of Cistanche tubulosa. Chem Pharm Bull (Tokyo) 2010;58(4):575-578.

[49]. Jayaraman R and Christina AJM. Evaluation of Citrullus colocynthis fruits on in vitro antioxidant activity and in vivo DEN/PB induced hepatotoxicity. International Journal of Applied Research in Natural Products 2013; 6 (1): 1-9.

[50]. Ali Esmail Al-snafi. Chemical constituents and pharmacological effects of Citrullus colocynthis - A review. IOSR Journal of Pharmacy 2016; 6(3): 57-67.

[51]. Abd El-baky AE, Amin HK. Effect of Citrullus colocynthis in ameliorating the oxidative stress and nephropathy in diabetic experimental rats. International Journal of Pharmaceutical Studies and Research 2011; 2: 1-10.

[52]. Ullah N, Khan MA, Asif AH, Khan T and Ahmad W. Citrullus colocynthis failed to combat against renal derangements, in spite of its strong antioxidant properties. Acta Pol Pharm 2013;70(3):533-538.

[53]. Shanmugam PST, Venkataraman S and Ariamuthu S. Cytoprotective activity of Citrus aurantifolia fruits extract against aflatoxin-B1 induced cytotoxicity. Int J Res Pharmacology Pharmacotherapy 2013; 2(2): 408-413.

[54]. -Bhavsar SK, Joshi P, Shah MB and Santani DD. Investigation into hepato-protective activity of Citrus limon. Pharmaceutical Biology 2007; 45(4): 303-311.

[55]. Chavada Kalpeshisinh S, Fadadu Kumar N, Patel Kirti N, Patel Kalpana G and Gandhi Tejal R. Effect of flavonoid rich fraction of Citrus medica Linn. on ethylene glycol induced urolithiasis in rats. J Drug Deli Therap 2012; 2 (4): 109-116.

[56]. Mehmet K, Fatma I, Hasan A, Aydin H, Mehmet T and Hanefi O. Evaluation of hepatoprotective activity of Bergamot orange in rats. Eastern Journal of Medicine 2005; 10: 1 - 4.

[57]. Chourasiya RK, Jain PK, Ganesh N, Nayak SS and Agrawal RK. Chromosomal aberration and tissue protection of Clerodendron inerme(l) Gaertn leaves. National Conference on "Recent Advances in Herbal Drug Technology" 26 \& 27 March 2010, Lakshmi Narain College of Pharmacy, Bhopal.

[58]. Al-Snafi AE. Chemical constituents and pharmacological effects of Clerodendrum inerme-A review. SMU Medical Journal 2016; 3(1): 129-153.

[59]. Rabiul H, Subhasish M, Sinha S, Roy MG, Sinha D and Gupta S. Hepatoprotective activity of Clerodendron inerme against paracetamol induced hepatic injury in rats for pharmaceutical product International Journal of Drug Development \& Research 2011; 3(1): 118-126.

[60]. Patil AP and Patil VR. Comparative evaluation of hepatoprotective potential of roots of blue and white flowered varieties of Clitoria ternatea Linn. Der Pharmacia Sinica 2011; 2(5):128-137.

[61]. Al-Snafi AE. Pharmacological importance of Clitoria ternatea - A review IOSR Journal of Pharmacy 2016; 6(3): 68-83.

[62]. Sarumathy K, Rajan MSD, Vijay T and Jayakanthi J. Evaluation of phytoconstituents, nephro-protective and antioxidant activities of Clitoria ternatea. Journal of Applied Pharmaceutical Science 2011; 1 (5): 164-172.

[63]. Iamsaard S, Burawat J, Kanla P, Arun S, Sukhorum W, Sripanidkulchai B, Uabundit N, Wattathorn J, Hipkaeo W, Fongmoon D and Kondo H. Antioxidant activity and protective effect of Clitoria ternatea flower extract on testicular damage induced by ketoconazole in rats. J Zhejiang Univ Sci B 2014;15(6):548-555.

[64]. Ali M, Qadir MI, Saleem M, Janbaz KH, Gul H, Hussain L and Ahmad B. Hepatoprotective potential of Convolvulus arvensis against paracetamol-induced hepatotoxicity. Bangladesh J Pharmacol 2013; 8: 300-304.

[65]. Al-Snafi AE. The chemical constituents and pharmacological effects of Convolvulus arvensis and Convolvulus scammonia- A review. IOSR Journal of Pharmacy 2016; 6(6): 64-75.

[66]. Ashour OM, Abdel-Naim AB, Abdallah HM, Nagy AA, Abdel-Naim AB and Abdallah HM. Evaluation of the potential cardioprotective activity of some Saudi plants against doxorubicin toxicity. Z. Naturforsch. 2011; 67 c: 297-307.

[67]. Al-Snafi AE. The Pharmacological and therapeutic importance of Cordia myxa- A review. IOSR Journal of Pharmacy 2016; 6(6): 47-57. 
[68]. Afzal M, Obuekwe C, Khan AR and Barakat H. Influence of Cordia myxa on chemically induced oxidative stress. Nutrition \& Food Science 2009; 39(1): 6-15.

[69]. Afzal M, Obuekwe C, Khan AR and Barakat H. Antioxidant activity of Cordia myxa L. and its hepatoprotective potential. EJEAF Che 2007; 8(6): 2236-2242.

[70]. Abdul Hamza NN and Al-Tahan FJ. Improvement of blood parameters by using Cordia myxa Linn. fruit extract with a dose of mefenamic acid (Ponstan). Proceeding of the ninth veterinary scientific conference- Baghdad. 2009; 2: 490-497.

[71]. Farag MFS. Evaluation of radio protective effects of Coriander (Coriandrum sativum L.) in male rats. Arab Journal of Nuclear Science and Applications 2013; 46(1): 240-249.

[72]. Ramadan MM and Abd Algader NNE. Chemopreventive effect of Coriandrum sativum fruits on hepatic toxicity in male rats. World Journal of Medical Sciences 2013; 8 (4): 322-333.

[73]. Sreelatha S, Padma PR and Umadevi M. Protective effects of Coriandrum sativum extracts on carbon tetrachloride-induced hepatotoxicity in rats. Food Chem Toxicol 2009; 47(4): 702-708.

[74]. A, Bigoniya P, Raj V, and Patel AA. Pharmacological screening of Coriandrum sativum Linn. for hepatoprotective activity. J Pharm Bioallied Sci 2011; 3(3): 435-441.

[75]. Samojlik I, Lakić N, Mimica-Dukić N, Daković-Svajcer K and Bozin B. Antioxidant and hepatoprotective potential of essential oils of coriander (Coriandrum sativum L.) and caraway (Carum carvi L.) (Apiaceae). J Agric Food Chem 2010;58(15):8848-8853.

[76]. Anilakumar KR, Khanum F and Bawa AS. Effect of coriander seed powder (CSP) on 1, 2-dimethyl hydrazine-induced changes in antioxidant enzyme system and lipid peroxide formation in rats. J Diet Suppl 2010;7(1):9-20.

[77]. Aga M, Iwaki K, Ueda Y, Ushio S, Masaki N, Fukuda S, Kimoto T, Ikeda M and Kurimoto M. Preventive effect of Coriandrum sativum (Chinese parsley) on localized lead deposition in ICR mice. J Ethnopharmacol 2001; 77(2-3): 203-208.

[78]. V, Kansal L, Sharma A, Lodi S and Sharma SH. Ameliorating effect of Coriandrum sativum extracts on hematological and immunological variables in an animal model of lead intoxication. Journal of Pharmacy and Allied Health Sciences 2011; 1: 16-29.

[79]. Sharma V, Kansal L and Sharma A. Prophylactic efficacy of Coriandrum sativum (Coriander) on testis of lead-exposed mice. Biol Trace Elem Res 2010; 136(3): 337-354.

[80]. Velaga MK, Yallapragada PR, Williams D, Rajanna S and Bettaiya R. Hydroalcoholic seed extract of Coriandrum sativum (Coriander) alleviates lead-induced oxidative stress in different regions of rat brain. Biol Trace Elem Res 2014; 159(1-3): 351-363.

[81]. Kansal L, Sharma V, Sharma A, Lodi S and Sharma SH. Protective role of Coriandrum sativum (coriander) extracts against lead nitrate induced oxidative stress and tissue damage in the liver and kidney in male mice. International Journal of Applied Biology and Pharmaceutical Technology 2011; 2(3): 6583.

[82]. Haddad F, Moghimi A, Salmani A, Rahimi MF and Gawam-Nasiri MR. Analysing the radioprotective effect of Cotoneaster nummularia in mouse bone marrow cells using micronucleus assay. Journal of Cell and Molecular Research 2009; 1(2): 77-83.

[83]. Shati AA, Elsaid FG and Hafez EE. Biochemical and molecular aspects of aluminium chloride-induced neurotoxicity in mice and the protective role of Crocus sativus L. extraction and honey syrup. Neuroscience 2011; 175: 66-74.

[84]. Al-Snafi AE. The pharmacology of Crocus sativus- A review. IOSR Journal of Pharmacy 2016; 6(6): 838.

[85]. Linardaki ZI, Orkoula MG, Kokkosis AG, Lamari FN and Margarity M. Investigation of the neuroprotective action of saffron (Crocus sativus L.) in aluminum-exposed adult mice through behavioral and neurobiochemical assessment. Food Chem Toxicol 2013; 52: 163-170.

[86]. Ghazavi A, Mosayebi G, Salehi H and Abtahi H. Effect of ethanol extract of saffron (Crocus sativus L.) on the inhibition of experimental autoimmune encephalomyelitis in C57bl/6 mice. Pak J Biol Sci 2009; 12(9): 690-695.

[87]. 87-Mousavi SH, Tayarani NZ and Parsaee H. Protective effect of saffron extract and crocin on reactive oxygen species-mediated high glucose-induced toxicity in PC12 cells. Cell Mol Neurobiol 2010; 30(2):185-191.

[88]. 88-Moallem SA, Hariri AT, Mahmoudi M and Hosseinzadeh H. Effect of aqueous extract of Crocus sativus L. (saffron) stigma against subacute effect of diazinon on specific biomarkers in rats. Toxicol Ind Health 2014; 30(2): 141-146.

[89]. Saleem S, Ahmad M, Ahmad AS, Yousuf S, Ansari MA, Khan MB, Ishrat T and Islam F. Effect of saffron (Crocus sativus) on neurobehavioral and neurochemical changes in cerebral ischemia in rats. $\mathrm{J}$ Med Food 2006; 9(2): 246-253. 
[90]. Hosseinzadeh H, Sadeghnia HR, Ghaeni FA, Motamedshariaty VS and Mohajeri SA. Effects of saffron (Crocus sativus L.) and its active constituent, crocin, on recognition and spatial memory after chronic cerebral hypoperfusion in rats. Phytother Res 2012; 26(3): 381-386.

[91]. Samarghandian S, Azimi-Nezhad M and Samini F. Ameliorative effect of saffron aqueous extract on hyperglycemia, hyperlipidemia, and oxidative stress on diabetic encephalopathy in streptozotocin induced experimental diabetes mellitus. Biomed Res Int 2014; doi: 10.1155/2014/920857.

[92]. Bandegi AR, Rashidy-Pour A, Vafaei AA and Ghadrdoost B. Protective effects of Crocus sativus L extract and crocin against chronic-stress induced oxidative damage of brain, liver and kidneys in rats. Adv Pharm Bull 2014; 4(Suppl 2): 493-499.

[93]. Omidi A, Riahinia N, Montazer Torbati MB and Behdani MA. Hepatoprotective effect of Crocus sativus (saffron) petals extract against acetaminophen toxicity in male Wistar rats. Avicenna J Phytomed 2014; 4(5): 330-336.

[94]. Pan TL, Wu TH, Wang PW, Leu YL, Sintupisut N, Huang CH, Chang FR and Wu YC. Functional proteomics reveals the protective effects of saffron ethanolic extract on hepatic ischemia-reperfusion injury. Proteomics. 2013; 13(15): 2297-2311.

[95]. Mohajeri D, Doustar Y, Rezaei A and Mesgari-Abbasi M. Hepatoprotective effect of ethanolic extract of Crocus sativus L. (Saffron) stigma in comparison with silymarin against rifampin induced hepatotoxicity in rats. ZJRMS 2010; 12(5): 53-59.

[96]. Lin JK and Wang CJ. Protection of crocin dyes on the acute hepatic damage induced by aflatoxin B1 and dimethylnitrosamine in rats. Carcinogenesis. 1986;7:595-599.

[97]. Hosseinzadeh H, Abootorabi A and Sadeghnia HR. Protective effect of Crocus sativus stigma extract and crocin (trans-crocin 4) on methyl methanesulfonate-induced DNA damage in mice organs. DNA Cell Biol 2008; 27(12): 657-764.

[98]. Premkumar K, Thirunavukkarasu C, Abraham SK, Santhiya ST and Ramesh A. Protective effect of saffron (Crocus sativus L.) aqueous extract against genetic damage induced by anti-tumor agents in mice. Hum Exp Toxicol 2006; 25(2): 79-84.

[99]. Premkumar K, Abraham SK, Santhiya ST, Gopinath PM and Ramesh A. Inhibition of genotoxicity by saffron (Crocus sativus L.) in mice. Drug Chem Toxicol 2001; 24(4): 421-428.

[100]. Abe K, Sugiura M, Yamaguchi S, Shoyama Y and Saito H. Saffron extract prevents acetaldehydeinduced inhibition of long-term potentiation in the rat dentate gyrus in vivo. Brain Res 1999; 851(1-2): 287-289.

[101]. Premkumar K, Abraham SK, Santhiya ST and Ramesh A. Protective effects of saffron (Crocus sativus Linn.) on genotoxins-induced oxidative stress in Swiss albino mice. Phytother Res 2003; 17(6): 614-617.

[102]. Premkumar K, Abraham SK, Santhiya ST and Ramesh A. Inhibitory effects of aqueous crude extract of Saffron (Crocus sativus L) on chemical-induced genotoxicity in mice. Asia Pac J Clin Nutr 2003; 12(4): 474-476.

[103]. El Daly ES. Protective effect of cysteine and vitamin E, Crocus sativus and Nigella sativa extracts on cisplatin-induced toxicity in rats. J Pharm Belg 1998; 53(2): 87-93.

[104]. El Daly ES. Protective effect of cysteine and vitamin E, Crocus sativus and Nigella sativa extracts on cisplatin- induced toxicity in rats. Journal of Islamic Academy of Sciences 1996; 9(4): 105-118.

[105]. Ajami M, Eghtesadi S, Pazoki-Toroudi H, Habibey R and Ebrahimi SA. Effect of Crocus sativus on gentamicin induced Nephrotoxicity. Biol Res 2010; 43: 83-90.

[106]. Sakr SA, Zowail ME and Marzouk AM. Effect of saffron (Crocus sativus L.) on sodium valporate induced cytogenetic and testicular alterations in albino rats. Anat Cell Biol 2014; 47(3): 171-179.

[107]. Nair SC, Salomi MJ, Panikkar B and Panikkar KR. Modulatory effects of Crocus sativus and Nigella sativa extracts on cisplatin-induced toxicity in mice. J Ethnopharmacol 1991; 31(1): 75-83.

[108]. Rahila KC, Bhatt L, Chakraborty M and Kamath JV. Hepatoprotective activity of Crotalaria juncea against thioacetamide intoxicated rats. Int Res J Pharm App Sci 2013; 3(1): 98-101.

[109]. Al-Snafi AE. The contents and pharmacology of Crotalaria juncea- A review. IOSR Journal of Pharmacy 2016; 6(6): 77-86.

[110]. Kumar A, Singh JK, Ali M, Kumar R, Kumar A, Nath A, Roy AK, Roy SP and Singh JK. Evaluation of Cuminum cyminum and Coriandrum sativum on profenofos induced nephrotoxicity in Swiss albino mice. Elixir Appl Botany 2011; 39 : 4771-4773.

[111]. Al-Snafi AE. The pharmacological activities of Cuminum cyminum - A review. IOSR Journal of Pharmacy 2016; 6(6): 46-65.

[112]. Elhabib EM. Homeida MMA and Adam SEI. Effect of combined paracetamol and Cuminum cyminum or Nigella sativa used in Wistar Rats. Journal of Pharmacology and Toxicology 2007; 2: 653659. 
[113]. Sakhaee E, Emadi L, Azari O, Kheirandish R, Esmaili Nejad MR and Shafiei BH. Effects of Cuminum cyminum $\mathrm{L}$ essential oil on some epididymal sperm parameters and histopathology of testes following experimentally induced copper poisoning in mice. Andrologia. 2015, doi: 10.1111/and.12476.

[114]. Al-Snafi AE. Medical importance of Cupressus sempervirens- A review. IOSR Journal of Pharmacy 2016; 6(6): 66-76.

[115]. Ali SA, Rizk MZ, Ibrahim NA, Abdallah MS, Sharara HM and Moustafa MM. Protective role of Juniperus phoenicea and Cupressus sempervirens against $\mathrm{CCl}_{4}$. World $\mathrm{J}$ Gastrointest Pharmacol Ther 2010;1(6): 123-131.

[116]. Donya SM and Ibrahim NH. Antimutagenic potential of Cynara scolymus, Cupressus sempervirens and Eugenia jambolana against paracetamol-induced liver cytotoxicity. Journal of American Science 2012; 8(1): 61-67.

[117]. Koriem KMM. Lead toxicity and the protective role of Cupressus sempervirens seeds growing in Egypt. Rev Latinoamer Quím 2009; 37(3): 230-242.

[118]. Ganapaty S, Ramaiah M, Yasaswini K and Kumar CR. Determination of total phenolic, flavonoid, alkaloidal contents and in vitro screening for hepatoprotective activity of Cuscuta epithymum (L) whole plant against $\mathrm{CCl}_{4}$ induced liver damage animal model. Int J Pharm Pharm Sci 2013; 5( 4):738-742.

[119]. Osman AG, Koutb M and Sayed Ael-D. Use of hematological parameters to assess the efficiency of quince (Cydonia oblonga Miller) leaf extract in alleviation of the effect of ultraviolet-A radiation on African catfish Clarias gariepinus (Burchell, 1822). J Photochem Photobiol B 2010; 99(1): 1-8.

[120]. Al-Snafi AE. The medical importance of Cydonia oblonga- A review. IOSR Journal of Pharmacy 2016; 6(6): 87-99.

[121]. Jouyban A, Shoja MM, Ardalan MR, Khoubnasabjafari M, Sadighi A, Tubbs RS, Agutter PS and Ghabili K. The effect of quince leaf decoction on renal injury induced by hypercholesterolemia in rabbits: A pilot study. Journal of Medicinal Plants Research 2011; 5(21): 5291-5295.

[122]. Othman MB, Han J, El Omri A, Ksouri R, Neffati M and Isoda H. Antistress effects of the ethanolic extract from Cymbopogon schoenanthus growing wild in Tunisia. Evidence-Based Complementary and Alternative Medicine 2013; http://dx. doi.org/10.1155/2013/737401

[123]. Al Haznawi AM, Attar AS, Abdulshakoor AA and Ramadan MA. Inhibition of calcium oxalate nephrotoxicity with Cymbopogon schoenanthus (Al-Ethkher). MSc thesis. Faculty of Applied Medical Sciences, Saudi Arabia 2007.

[124]. Chidrawar VR, Chitme HR, Patel KN, Patel NJ, Racharla VR, Dhoraji NC and Vadalia KR. Effects of Cynodon dactylon on stress-induced infertility in male rats. Pharmacognosy 2011; 3(1): 26-35.

[125]. Kowsalya R, Kaliaperumal J, Vaishnavi M, and Namasivayam E. Anticancer activity of Cynodon dactylon $\mathrm{L}$ root extract against diethyl nitrosamine induced hepatic carcinoma. South Asian J Cancer 2015; 4(2): 83-87.

[126]. Jain A, Jain IP, Singh Sp and Agrawal A. To evaluate hepatoprotective activity of roots of Cynodon dactylon - An experimental study. Asian J Pharm Clin Res 2013; 6(2):109-112.

[127]. Sumathi T, Shobana C, Kumari BR and Nandhini DN. Protective role of Cynodon dactylon in ameliorating the aluminium-induced neurotoxicity in rat brain regions. Biol Trace Elem Res 2011; 144(1-3): 843-853.

[128]. Mousa-Al-Reza H, Rad AK, Rajaei Z, Sadeghian MH, Hashemi N and Keshavarzi Z. Preventive effect of Cynodon dactylon against ethylene glycol-induced nephrolithiasis in male rats. Avicenna $\mathrm{J}$ Phytomed 2011; 1(1): 14-23.

[129]. Khajavi Rad A, Hadjzadeh MA, Rajaei Z, Mohammadian N, Valiollahi S and Sonei M. The beneficial effect of Cynodon dactylon fractions on ethylene glycol-induced kidney calculi in rats. Urol J 2011; 8(3): 179-184.

[130]. Al-Snafi AE. Chemical constituents and pharmacological effects of Cynodon dactylon- A review. IOSR Journal Of Pharmacy 2016; 6(7): 17-31.

[131]. Al-Snafi AE. A review on Cyperus rotundus A potential medicinal plant. IOSR Journal Of Pharmacy 2016; 6(7): 32-48.

[132]. Oh GS, Yoon J, Lee GG, Kwak JH and Kim SW. The Hexane fraction of Cyperus rotundus prevents non-alcoholic fatty liver disease through the inhibition of liver X receptor $\alpha$-mediated activation of sterol regulatory element binding protein-1c. Am J Chin Med. 2015; 43(3): 477-494.

[133]. -Lee CH, Hwang DS, Kim HG, Oh H, Park H, Cho JH, Lee JM, Jang JB, Lee KS and Oh MS. Protective effect of Cyperi rhizoma against 6-hydroxydopamine-induced neuronal damage. J Med Food 2010; 13(3): 564-571.

[134]. Dabaghian FH, Hashemi M, Entezari M, Movassaghi S, Goushegir SA, Kalantari S, Movafagh A and Sharifi ZN. Effect of Cyperus rotundus on ischemia-induced brain damage and memory dysfunction in rats. Iran J Basic Med Sci 2015; 18(2): 199-204. 
[135]. Sunil AG, Kesavanarayanan KS, Kalaivani P, Sathiya S, Ranju V, Priya RJ, Pramila B, Paul FD, Venkhatesh $\mathbf{J}$ and Babu CS. Total oligomeric flavonoids of Cyperus rotundus ameliorates neurological deficits, excitotoxicity and behavioral alterations induced by cerebral ischemic-reperfusion injury in rats. Brain Res Bull 2011; 84(6): 394-405.

[136]. Jebasingh D, Devavaram Jackson D, Venkataraman S, Adeghate E and Starling Emerald B. The protective effects of Cyperus rotundus on behavior and cognitive function in a rat model of hypoxia injury. Pharm Biol 2014; 52(12): 1558-1569.

[137]. Hemanth Kumar K, Tamatam A and Pal A, Khanum F. Neuroprotective effects of Cyperus rotundus on SIN-1 induced nitric oxide generation and protein nitration: ameliorative effect against apoptosis mediated neuronal cell damage. Neurotoxicology 2013; 34: 150-159. 